\title{
Cancer-induced anorexia in tumor-bearing mice is dependent on cyclooxygenase- 1
}

Johan Ruud, Anna Nilsson, Linda Engström Ruud, Wenhua Wang, Camilla Nilsberth, BrittMarie Iresjo, Kent Lundholm, David Engblom and Anders Blomqvist

\section{Linköping University Post Print}

N.B.: When citing this work, cite the original article.

Original Publication:

Johan Ruud, Anna Nilsson, Linda Engström Ruud, Wenhua Wang, Camilla Nilsberth, BrittMarie Iresjo, Kent Lundholm, David Engblom and Anders Blomqvist, Cancer-induced anorexia in tumor-bearing mice is dependent on cyclooxygenase-1, 2013, Brain, behavior, and immunity, (29), 124-135.

http://dx.doi.org/10.1016/j.bbi.2012.12.020

Copyright: Elsevier

http://www.elsevier.com/

Postprint available at: Linköping University Electronic Press http://urn.kb.se/resolve?urn=urn:nbn:se:liu:diva-90188 


\section{Cancer-induced anorexia in tumor-bearing mice is dependent on cyclooxygenase-1}

Johan Ruud ${ }^{1}$, Anna Nilsson ${ }^{1}$, Linda Engström Ruud ${ }^{1}$, Wenhua Wang ${ }^{2}$, Camilla Nilsberth ${ }^{1}$, Britt-Marie Iresjö $^{2}$, Kent Lundholm ${ }^{2}$, David Engblom ${ }^{1}$, Anders Blomqvist ${ }^{1}$

${ }^{1}$ Division of Cell Biology, Department of Clinical and Experimental Medicine, Medical Faculty, Linköping University, S-581 85 Linköping, Sweden; and ${ }^{2}$ Department of Surgery, Institute of Clinical Sciences, Sahlgrenska Academy, Sahlgrenska University Hospital, S-413 45 Gothenburg, Sweden

35 pages, including 1 table, 4 figures

Conflict of interest statement: All authors declare that there are no conflicts of interest.

Correspondence to: Dr. Anders Blomqvist, Division of Cell Biology, Department of Clinical and Experimental Medicine, Medical Faculty, Linköping University, S-581 85 Linköping, Sweden. Phone: +46 10 1033193; E-mail: anders.blomqvist@liu.se 


\begin{abstract}
It is well-established that prostaglandins (PGs) affect tumorigenesis, and evidence indicates that PGs also are important for the reduced food intake and body weight loss, the anorexiacachexia syndrome, in malignant cancer. However, the identity of the PGs and the PG producing cyclooxygenase $(\mathrm{COX})$ species responsible for cancer anorexia-cachexia is unknown. Here, we addressed this issue by transplanting mice with a tumor that elicits anorexia. Meal pattern analysis revealed that the anorexia in the tumor-bearing was due to decreased meal frequency. Treatment with a non-selective COX inhibitor attenuated the anorexia, and also tumor growth. When given at manifest anorexia, non-selective COXinhibitors restored appetite and prevented body weight loss without affecting tumor size. Despite COX-2 induction in the cerebral blood vessels of tumor-bearing mice, a selective COX-2 inhibitor had no effect on the anorexia, whereas selective COX-1 inhibition delayed its onset. Tumor growth was associated with robust increase of $\mathrm{PGE}_{2}$ levels in plasma - a response blocked both by non-selective COX-inhibition and by selective COX-1 inhibition, but not by COX-2 inhibition. However, there was no increase in $\mathrm{PGE}_{2}$-levels in the cerebrospinal fluid. Neutralization of plasma $\mathrm{PGE}_{2}$ with specific antibodies did not ameliorate the anorexia, and genetic deletion of microsomal PGE synthase-1 (mPGES-1), affected neither anorexia nor tumor growth. Furthermore, tumor-bearing mice lacking $\mathrm{EP}_{4}$ receptors selectively in the nervous system developed anorexia. These observations suggest that COXenzymes, most likely COX-1, are involved in cancer-elicited anorexia and weight loss, but that these phenomena occur independently of host mPGES-1, $\mathrm{PGE}_{2}$ and neuronal $\mathrm{EP}_{4}$ signaling.
\end{abstract}

Key words: cancer anorexia-cachexia, cyclooxygenase, microsomal prostaglandin E synthase1, prostaglandin E2 


\section{Introduction}

Cachexia, characterized by metabolic derangements leading to weight loss, is a severe problem in several chronic diseases, particularly malignant cancer (Fearon et al., 2011; Tisdale, 2010). Cachexia restricts the patients' tolerance and response to treatment, causes suffering and impaired quality of life, and reduces life expectancy. Cachexia differs from starvation in which weight loss induced by caloric restriction normally is followed by compensatory re-feeding mechanisms. In cancer anorexia, the expected counter-regulatory feeding response to reduced body mass is absent, indicating an uncoupling of food intake from energy expenditure (Bosaeus et al., 2001). Indeed, the weight loss in cachexia is paradoxically associated with anorexia (persistent satiety or un-desire to eat) leading to reduced food intake. Since feeding and body weight are subject to close regulation by brain homeostatic and hedonic systems, cancer-induced anorexia is likely due to a complex interplay of mediators acting on the brain but our understanding of the pathophysiology underlying reduced appetite in cancer is incomplete. However, inflammatory signaling is a central theme in cancer anorexia (Gelin et al., 1991; Ruud et al., 2010). In particular, inflammatory-induced prostaglandins have been proposed as key mediators (Cahlin et al., 2000b; Sandstrom et al., 1990). Among the prostaglandins, prostaglandin $\mathrm{E}_{2}\left(\mathrm{PGE}_{2}\right)$ is of special interest, since inhibition or deletion of the inducible cyclooxygenase $(\mathrm{COX}-2)$ or the inducible terminal $\mathrm{PGE}_{2}$ isomerase, microsomal prostaglandin E synthase-1 (mPGES-1), largely prevents the anorexia during acute inflammation (Elander et al., 2007; Lugarini et al., 2002; Pecchi et al., 2006). Furthermore, induced synthesis of COX-2 and $\mathrm{PGE}_{2}$ are critical in formation of many malignant tumors, foremost colorectal cancer (Brown and DuBois, 2005). Thus, epidemiological studies have revealed that administration of traditional non-steroidal anti-inflammatory drugs, as well as selective COX-2 inhibitors, is associated with decreased incidence of colorectal cancer (Steinbach et al., 2000), and selective inhibition of mPGES-1 
with the supposedly added safety over COX and COX-2 inhibitors has emerged as an attractive approach for treating malignancies (Murakami and Kudo, 2006).

Here we hypothesized that the $\mathrm{PGE}_{2}$ synthesizing pathway also plays a role for the reduced food intake and body weight loss in cancer disease. We tested this hypothesis by examining the role of COX-1, COX-2, mPGES-1, and $\mathrm{PGE}_{2}$ and its $\mathrm{EP}_{4}$ receptor for the development of cancer-induced anorexia and weight loss in a mouse tumor model. In this model mice are inoculated with a methylcholanthrene-induced sarcoma MCG 101 (Lundholm et al., 1978), a non-metastasizing, undifferentiated epithelial-like solid tumor (Lonnroth et al., 1995). This tumor model has been used extensively in the Lundholm laboratory for the study of cancer cachexia. When implanted subcutaneously the tumors grow locally with a reproducible growth pattern. The animals die because of cancer cachexia 12-15 days after tumor implantation (Lundholm et al., 1978). We recently showed that mice lacking MyD88, an adaptor protein critical for Toll-like and IL-1 receptor family signaling, were protected against MCG 101-induced anorexia (Ruud et al., 2010), demonstrating the importance of inflammatory signaling for the reduced food intake in this model.

\section{Materials and methods}

\subsection{Animals, tumor or sham implantations, and food intake monitoring}

Adult and age-matched female wild-type mice (Taconic, Ejby, Denmark; Scanbur, Stockholm, Sweden; or Jackson, Sulzfeld, Germany), and genetically modified mice and their littermates $\left[\right.$ Ptges $^{-/-}$(mPGES-1 deficient; (Trebino et al., 2003), Ptgs2 ${ }^{-/-}$(COX-2 knock-out; on a mixed B6;129P2 background; from Taconic), EP4 $4^{\text {floxflox }}$ (Schneider et al., 2004), NestinCre deleter (Tronche et al., 1999)], all on a C57BL/6 background if not otherwise stated, were used. Mice lacking the $\mathrm{EP}_{4}$ receptor in neural cells $\left(\mathrm{EP} 4^{\Delta \text { Nestin-Cre }}\right)$ and their control littermates

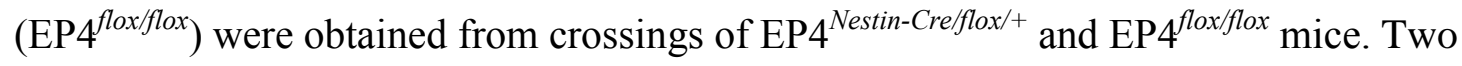


fragments (3-4 $\left.\mathrm{mm}^{3}\right)$ of the methylcholanthrene-induced sarcoma MCG 101 (Lundholm et al., 1978) were placed subcutaneously under gas anesthesia (4 \% isoflurane; Abbott Laboratories, Abbott Park, IL) on both sides of the dorsal midline using a tuohy needle. Control mice were handled in the same way but injections were done without tumor fragments (sham). Food intake was monitored in two ways: 1) The animals were housed in cages carrying raised bottom wire grids (Tecniplast, Varese, Italy) in a temperature-controlled $\left(\sim 20{ }^{\circ} \mathrm{C} \pm 1.5\right)$ environment and on a regular $12 \mathrm{~h}$ daylight schedule (lights on and off at 07/19 h), with free access to standard rodent laboratory pelleted chow (CRM-E, Special Diets Services, Witham, Essex, UK) and tap water. Food intake was registered on a daily basis with the measurements carried out during the light phase. Food spillage was corrected for, by collecting the gnaw waste, which was weighed; 2) Food intake was recorded continuously via an automated feeding monitoring equipment (AccuScan Instruments, Columbus, $\mathrm{OH}$ ) that allowed uninterrupted, undisturbed recordings of individual meals for each animal, as described elsewhere (Elander et al., 2007). In this setting, powdered food was used to limit spillage and hoarding of the diet. Feeding activity was retrieved every $\sim 1.5 \mathrm{~s}$ and processed using DietDat and DietMax software (AccuScan Instruments). A meal was defined as whenever at least 0.01 $\mathrm{g}$ of food was removed from the food tray and considered terminated if the food was left undisturbed for $\geq 5 \mathrm{~min}$. Using this set-up, the daily food intake monitored amounts to $~ 95 \%$ of the total food intake recorded via manual readings (Elander et al., 2007).

The endpoint of the tumor-implantation experiments was for animal ethics reasons set to 10 days post implantation. However, when data permitted, i.e. a clear anorexic response was seen irrespective of treatment for two consecutive days, the experiment was terminated earlier, to minimize animal suffering.

All experiments were approved by the Animal Ethics Committee in Linköping. All reagents were from Sigma-Aldrich (St. Louis, MO) if not otherwise specified. 


\subsection{Drugs}

Indomethacin [(Alpharma-Isis GmbH \& Co KG, Langenfeld, Germany); $1 \mu \mathrm{g} / \mathrm{g}$ body weight; (Axelsson et al., 2005)], Liometacen ${ }^{\circledR}$ (Indomethacin Meglumine; Chiesi Farmaceutici S.P.A., Parma, Italy; $1 \mu \mathrm{g} / \mathrm{g}$ body weight), sodium naproxen (100-150 $\mu \mathrm{g} / \mathrm{g}$ body weight), or parecoxib (Dynastat ${ }^{\circledR}$, Pfizer, Sandwich, Kent, UK; $100 \mu \mathrm{g} / \mathrm{g}$ body weight; dose titrated here to completely obliterate the febrile response to lipopolysaccharide (LPS)) were provided via the drinking water. The concentration of the drugs in the water was calculated with account taken for the reduced water consumption that results from reduced food intake. The COX-1 inhibitor SC560 (5-(4-chlorophenyl)-1-(4-methoxyphenyl)-3-(trifluoromethyl)-1H-pyrazole; Cayman Chemical, Ann Arbor, MI) was administered in specially prepared food pellets (AIN76A; Research Diets Inc., Brunswick, NJ) containing 225 mg SC560 per kg food. At a daily food intake of $4 \mathrm{~g}$, the ingested dose ( $30 \mathrm{mg} / \mathrm{kg}$ body weight) has been shown to completely inhibit the formation of $\mathrm{TXB}_{2}$ [the stable metabolite of COX-1 dependent $\mathrm{TXA}_{2}$ formation (Smith et al., 1998)] and to prevent the rapid increase in plasma corticosterone induced by LPS, that is dependent on COX-1 (Elander et al., 2010), without interfering with COX-2 dependent mechanisms (Elander et al., 2010; Smith et al., 1998).

\subsection{RNA isolation, and cDNA synthesis and quantitative real-time PCR}

Following asphyxiation in carbon dioxide, mice were rinsed from blood by transcardial perfusion with sterile saline. A block of the hypothalamus was dissected, immediately snapfrozen in liquid nitrogen, and kept at $-80^{\circ} \mathrm{C}$. RNA was extracted, quantified, and transcribed as previously described (Wang et al., 2005). Real-time PCR reactions were performed as singleplex on 10 ng of cDNA in duplicate for every sample in a 96-well format on the ABI Fast 7500 Real-Time PCR instrument using TaqMan® probes, primers, and the Fast 
Universal PCR Master Mix (Applied Biosystems, Foster City, CA). Assays were: Ptgs1 (Mm00477214_m1), Ptgs2 (Mm00478374_m1), and Ptger4 (Mm00436053_m1). Actb (Mm00607939_s1) served as endogenous control. Assays for terminal prostanoids enzymes are given in Table 1. Relative gene expression changes in tumor-bearing mice were calculated using the $2(-\Delta \Delta \mathrm{C}(\mathrm{T}))$ method and expressed as fold change compared with sham-implanted mice.

\subsection{Immunohistochemistry}

COX-2 was detected with a polyclonal affinity-purified IgG antibody raised in goat against a synthetic peptide consisting of amino acids 586-604 of mouse COX-2 (sc-1747, lot \# E2506; Santa Cruz) as previously described (Ruud and Blomqvist, 2007). The specificity of the antibody was tested by staining brain sections from wild-type and COX-2 null mice that had been subjected to an i.p. injection of LPS.

\subsection{Body temperature recordings}

Core body temperature was measured telemetrically, in individually caged mice, and at nearthermoneutral conditions $\left(28-30^{\circ} \mathrm{C}\right)$. One week prior to recordings, a miniature transmitter (Data Sciences International, St. Paul, MN) was implanted in the peritoneal cavity via a midline laparotomy under isoflurane gas anesthesia and with Temgesic ${ }^{\circledR}$ (RB Pharmaceuticals, Slough, UK) given i.p. peri-operatively. The abdominal wall was sutured back in layers. 


\subsection{Plasma and cerebrospinal fluid PGE analysis}

Following asphyxiation of the mice with $\mathrm{CO}_{2}$, blood was aspirated from the right cardiac atrium and transferred to EDTA-covered tubes (Sarstedt, Nümbrecht, Germany).

Indomethacin was added, to inhibit ex vivo prostanoid formation, to a final concentration of $10 \mu \mathrm{M}$, and the blood was centrifuged $\left(7,000 \mathrm{~g}, 4^{\circ} \mathrm{C}, 7 \mathrm{~min}\right)$. Hemolyzed samples were discarded. The concentration of PGE metabolites and $\mathrm{PGE}_{2}$ was determined with a Prostaglandin E Metabolite EIA Kit or a Luminex ${ }^{\circledR} \mathrm{xMAP}^{\circledR}$ Prostaglandin $\mathrm{E}_{2}$ kit (Cayman Chemical, Ann Arbor, MI), respectively.

For collection of cerebrospinal fluid (CSF), mice were mounted in a stereotaxic frame, and the head was flexed anteriorly to enable access to the suboccipital region. Under microscopic guidance, CSF was aspirated from the cerebellomedullary cistern using a Hamilton syringe, and immediately frozen on dry ice. The concentration of $\mathrm{PGE}_{2}$ was determined using a High Sensitivity Prostaglandin $E_{2}$ Enzyme Immunoassay Kit (Assay Designs, Ann Arbor, MI).

\subsection{In vivo $P G E_{2}$ neutralization}

Ten $\mathrm{mg} / \mathrm{kg}$ body weight of a mouse monoclonal antibody that binds $\mathrm{PGE}_{2}$ (clone 2B5;

Cayman Chemical Company, Ann Arbor, MI), or a control antibody (MOPC21; IgG1, $\kappa)$, matching 2B5 in isotype and concentration, was injected i.p. $9 \mathrm{~h}$ prior to lights out. Plasma levels of 2B5 after a single i.p. injection have been reported to peak within $6 \mathrm{~h}$, and to reach steady-state 18 h post-injection (Portanova et al., 1996). The dose used here has been shown to substantially reduce the $\mathrm{PGE}_{2}$-elicited nociceptive response to phenylbenzoquinone (Mnich et al., 1995), its analgesic effect being as potent as $1 \mathrm{mg} / \mathrm{kg}$ body weight of indomethacin given orally (the same doses used in the present study). It also completely reversed carrageenan-induced edema and hyperalgesia, as well as that of adjuvant-induced arthritis, 
with tissue $\mathrm{PGE}_{2}$ levels up to $8000 \mathrm{pg} / \mathrm{ml}$ (i.e. higher than in the present study; see Results and cf. (Wang et al., 2001), and was as effective as 2-30 mg/kg body weight of indomethacin given orally (Portanova et al., 1996; Zhang et al., 1997).

\subsection{Statistical analysis}

Food intake, carcass body weight, and concentrations of PGE metabolites and $\mathrm{PGE}_{2}$ in plasma were analyzed by a one-way ANOVA with Tukey's post-hoc. Gene expression values, tumor weights, $\mathrm{PGE}_{2}$ levels in the $\mathrm{CSF}$, temperature data, and meal pattern data were compared using an unpaired, two-tailed, $t$-test. $P<0.05$ was accepted as significantly different.

\section{Results}

\subsection{Tumor-bearing mice display decreased meal frequency}

Meal pattern analysis showed that between day 6 and 7 the tumor bearing mice displayed a significant reduction of food intake compared with sham-implanted mice $(P<0.05$; Fig. 1A). At anorexia onset, day 7, the reduced food intake in tumor-bearing mice was caused by a reduction in the number of meals/24 h $(P<0.05$; Fig. 1B), but not in meal size or meal duration (Fig. 1C-D). Food intake was affected during the night, but not during the day (Fig. 1E-F). In line with a reduced number of meals, inter-meal interval (IMI; time elapsed between meals) was significantly lengthened in tumor-bearing mice $(P<0.05$; Fig. $1 \mathrm{G})$, but no difference in satiety ratio (the quotient between IMI and meal size) or feeding rate (meal size/duration) was seen (data not shown). At day 10, when the tumor-bearing mice had displayed several days of anorexia, they still consumed considerably fewer meals than shamimplanted controls $(P<0.001 ;$ Fig. $1 \mathrm{H})$, but their meal size was on average slightly larger $(P$ $=0.04)$, and they displayed a prolonged meal duration $(P<0.01$; Fig. $1 \mathrm{I}-\mathrm{J})$ compared with sham-implanted mice, although the latter changes did not compensate for the reduced food 
intake caused by the reduced number of meals. As at day 7, night time meal-frequency was lower in tumor-bearing mice $(P<0.001$; Fig. $1 \mathrm{~K})$ than in sham-implanted control, whereas light phase meal frequency was unaffected (not shown). Similarly, satiety ratio and IMI (Fig.1L-M), but not feeding rate (not shown), were greater in tumor-bearing anorectic mice $(P$ $<0.01-0.001)$ than in sham-implanted controls.

\subsection{COX-inhibition attenuates cancer-elicited anorexia and tumor growth}

Tumor-bearing mice given indomethacin in the drinking water $(\sim 1 \mu \mathrm{g} / \mathrm{g}$ body weight $)$ showed attenuated anorexia compared with untreated controls (Fig. 2A), hence suggesting that cancer-induced anorexia in part is mediated by cyclooxygenases. However, as reported previously (Cahlin et al., 2005; Cahlin et al., 2000a), indomethacin also impaired tumor growth (Fig. 2B).

\subsection{COX-inhibition restores food intake independently of its effect on tumor growth}

We next examined if the attenuated anorexia seen in indomethacin-treated tumor- bearing mice could be explained by slower tumor growth, or whether indomethacin attenuated the anorexia independently of its effect on tumor growth. Indomethacin or vehicle was given to tumor-bearing mice with equally sized tumors when anorexia had been established for two consecutive days. During the two following days, indomethacin-treatment almost completely restored food intake to sham-control levels (Fig. 2C). By contrast, the food intake of the untreated tumor-bearing mice gradually decreased. In a second series, the experiment was repeated but with administration of sodium naproxen or Liometacen ${ }^{\circledR}$ (indomethacin meglumine salt). These drugs had the same effect on the food intake as indomethacin (Fig. 2D), thus abolishing the anorexia in the tumor-bearing animals. Notably, the short indomethacin treatment had no effect on tumor weight (Fig. 2E). These data hence suggest 
that the effect of COX-inhibition on food intake in tumor-bearing mice occurs independently of reduced tumor size.

Examination of the body weight after the tumor had been excised showed that untreated tumor-bearing mice had lost $\sim 7.5 \%$ in body weight compared with sham-implanted mice ( $P$ $<0.01$ ), whereas the tumor-bearing mice subjected to acute COX-inhibition displayed a body weight that was not significantly different from that of the sham-implanted mice (Fig. 2F).

\subsection{Central COX-2 expression is upregulated in tumor-bearing mice}

We next investigated if the anorexia was associated with induced prostaglandin synthesis in the brain. Such synthesis has been shown to be critical for interleukin-1 $\beta$ induced anorexia (Elander et al., 2007). Quantitative real-time PCR on cDNA, prepared from the hypothalamus, showed that COX-2 mRNA in untreated tumor-bearing mice was significantly upregulated compared with that in sham-implanted mice (Fig. 3A). Tumor-bearing mice that received indomethacin throughout the study period likewise showed elevated COX-2 mRNA levels compared with sham-operated controls, however, the difference did not reach statistical significance $(P=0.16)$. Immunohistochemical staining showed induced COX-2 immunoreactivity in cells associated with the cerebral vasculature of untreated tumor-bearing mice (Fig. 3B). Indomethacin-treated tumor-bearing mice also displayed COX-2 immunoreactivity in the vascular cells of the brain, whereas no staining was seen in cerebrovascular cells of sham-implanted controls.

Quantitative RT-PCR analysis of the hypothalamic expression of mPGES-1, known to be co-induced with COX-2 in the brain, showed no significant differences between tumorbearing mice and sham-implanted mice irrespective of treatment. Analyses of the expression of other terminal prostaglandin synthases showed that lipocalin-type PGD-synthase was increased by close to $50 \%(P<0.05)$, in tumor-bearing mice whereas there was no change in 
the expression of hematopoietic PGD-synthase, PGI-synthase, PGF-synthase, or thromoboxane A-synthase (Table 1).

\subsection{Anorexia occurs independently of $\mathrm{COX}-2$}

To examine the role of the induced COX-2 expression for cancer-induced anorexia, we treated tumor-bearing mice with a selective COX-2 inhibitor, parecoxib (100 mg/kg body weight, orally) or vehicle, when tumor-bearing mice displayed two consecutive days of reduced food intake compared with sham-implanted mice. In contrast to what was found when mice were given indomethacin or naproxen, food intake was unaffected by the COX-2 blockade (Fig. 3C). The same finding was obtained also after a higher dose of parecoxib given orally (150 mg/kg body weight) as well as after it was given intraperitoneally $(10 \mathrm{mg} / \mathrm{kg}$ body weight) $1 \mathrm{~h}$ prior to the onset of the dark period and again after six hours (Fig. 3C).

\subsection{Tumor-bearing mice are afebrile}

An often manifested sign of cancer is subfebrility (low-graded fever). Since COX-2 is critical for the development of inflammation-induced pyresis, and because COX-2 inhibition did not affect food intake in tumor-bearing mice, we next examined whether the increased COX-2 expression in the brain instead reflected an ongoing febrile response. We found, however, that core body temperature measured telemetrically during 10 consecutive days did not differ between tumor-bearing and sham-implanted mice (data not shown).

\subsection{Involvement of $C O X-1$ in cancer-induced anorexia: Initiation of anorexia via $C O X-1$}

The finding that non-selective COX-inhibition, but not specific COX-2 blockade, attenuated or reversed the anorexia in tumor-bearing mice, suggested that the anorexia is COX-1 dependent. We directly tested this hypothesis by examining the food intake in mice treated 
with a selective COX-1 inhibitor, SC560, given in the food pellets (225 mg/kg food). The results showed that non-treated treated tumor-bearing mice developed typical anorexia in contrast to SC560 treated tumor-bearing mice, whose food intake initially was comparable to that of sham-implanted mice (Fig. 3D). However, COX-1 inhibition only delayed the onset of anorexia, because the SC560 treated tumor-bearing mice displayed a similar reduction in food intake as the untreated tumor-bearing mice from day 8 and onwards (Fig. 3D). Thus, these data indicate that COX-1 is involved in eliciting the reduced food intake in this model. However, this involvement was not associated with increased transcription of COX-1. Thus, qPCR analysis of COX-1 mRNA at day 10 after tumor implantation showed on the contrary a small decrease (by $15 \% ; P<0.05$ ) in tumor bearing mice (but not when indomethacintreated) compared with sham-implanted mice.

\subsection{Plasma $P G E_{2}$ is markedly increased in tumor-bearing mice whereas $P G E_{2}$ levels in the} cerebrospinal fluid remain unchanged

We next sought to identify which metabolite downstream of COX that was responsible for the effect on appetite. We analyzed $\mathrm{PGE}_{2}$ and $\mathrm{PGE}$ metabolites in plasma and $\mathrm{PGE}_{2}$ in cerebrospinal fluid of tumor-bearing and sham-implanted mice, since central administration or systemic injection of $\mathrm{PGE}_{2}$ has been shown to suppress food intake (Levine and Morley, 1981; Ohinata et al., 2006; Wang et al., 2001), and since inflammation-induced anorexia is dependent on $\mathrm{PGE}_{2}$-synthesising enzymes (Elander et al., 2007; Pecchi et al., 2006). The results show that tumor-bearing mice displayed large elevations of plasma PGE metabolites and plasma $\mathrm{PGE}_{2}$, and that these effects were blocked by indomethacin (Fig, 4A-B). Furthermore, the elevation of plasma $\mathrm{PGE}_{2}$ was also blocked by the SC560 treatment, but not by treatment with parecoxib (Fig. 4D), indicating that COX-1, but not COX-2, was responsible for the increased levels of plasma $\mathrm{PGE}_{2}$. In contrast, the $\mathrm{PGE}_{2}$ levels in the 
cerebrospinal fluid were largely comparable to those in sham-implanted mice (Fig. 4C; $P=$ 0.16). Thus, these data show that tumor-induced anorexia is associated with elevated levels of $\mathrm{PGE}_{2}$ in the blood but not in the brain, and that anti-inflammatory treatment that reduces peripheral $\mathrm{PGE}_{2}$-levels restores appetite. However, these data also imply that the peripherally synthesized $\mathrm{PGE}_{2}$ in this model does not enter the brain, and hence is unlikely to influence central structures involved in the control of food intake. Furthermore, the data are also consistent with the tumor-bearing mice being afebrile, as fever is dependent on intracerebral $\mathrm{PGE}_{2}$ concentrations (Engblom et al., 2003).

\subsection{Host mPGES-1 is dispensable for cancer-induced anorexia}

Given that $\mathrm{PGE}_{2}$ was strongly elevated in tumor-bearing mice and that both indomethacin and SC560 reduced plasma $\mathrm{PGE}_{2}$ release and improved appetite, we next examined if induced $\mathrm{PGE}_{2}$ synthesis was critical for the development of anorexia in tumor-bearing mice. Mice with a disrupted Ptges gene, encoding mPGES-1, the inducible terminal isomerase for $\mathrm{PGE}_{2}$ synthesis, or their wild-type littermates were implanted with tumors or sham-implanted. The results show that the food intake of tumor-transplanted mPGES-1 knock-out mice mirrored that of wild-type tumor-bearing mice, i.e. they developed the same degree of anorexia (Fig. 4E). Furthermore, host mPGES-1 deficiency had no effect on MCG 101 tumor growth, since mice irrespective of Ptges genotype developed tumors of similar weights (Fig. 4G). Noteworthy, tumor-bearing mPGES-1 KO mice displayed similarly elevated levels of $\mathrm{PGE}_{2}$ in plasma as WT mice (Fig. 4D), indicating that the $\mathrm{PGE}_{2}$ production occurred in the tumor cells (Lonnroth et al., 1995), or through another terminal PGE $_{2}$-synthase than mPGES-1 (Samuelsson et al., 2007) than mPGES-1. 


\subsection{Neutralization of peripheral $P G E_{2}$ or conditional disruption of the $\mathrm{EP}_{4}$ receptor in the} nervous system does not alleviate tumor-induced anorexia

Because drugs that reduced the $\mathrm{PGE}_{2}$ increment in plasma improved appetite, and because $\mathrm{PGE}_{2}$ may be synthesized via mPGES-2 or cPGES (Samuelsson et al., 2007), or independently of host mPGES-1, we selectively neutralized the biological activity of $\mathrm{PGE}_{2}$ using a specific monoclonal antibody, clone 2B5, validated for in vivo experiments (Mnich et al., 1995; Portanova et al., 1996; Zhang et al., 1997). The anti $\mathrm{PGE}_{2}$ antibody was given i.p. (10 mg/kg body weight) to tumor-bearing mice after two consecutive days of anorexia, whereas control groups (tumor-bearing and sham-implanted mice) were given a control antibody matched to 2B5 in isotype and concentration. The results show that neutralization of peripheral $\mathrm{PGE}_{2}$ did not temper the anorexia in tumor-bearing mice (Fig. 4F). These data thus imply that circulating $\mathrm{PGE}_{2}$, while strongly elevated in this tumor model, does not elicit anorexia.

While analysis of the $\mathrm{PGE}_{2}$ content in the cerebrospinal fluid only showed a marginal increase in tumor-bearing mice, $\mathrm{PGE}_{2}$ can act in a paracrine manner, in close proximity to its synthesis, by binding to brain parenchymal prostaglandin receptors $\mathrm{EP}_{1-4}$. There is good evidence that the $\mathrm{EP}_{4}$ receptor is involved in $\mathrm{PGE}_{2}$ elicited anorexia. Thus, intracerebroventricularly injected $\mathrm{EP}_{4}$ agonists, but not agonists to the other $\mathrm{PGE}_{2}$ receptors, mimic $\mathrm{PGE}_{2}$ induced anorexia, and the anorexia elicited by central injection of $\mathrm{PGE}_{2}$ can be blocked by an $\mathrm{EP}_{4}$ antagonist (Ohinata et al., 2006).

To determine if the $\mathrm{EP}_{4}$ receptor expressing cells in the nervous system are critical for the anorexia, we selectively ablated $\mathrm{EP}_{4}$ receptors using Nestin-Cre and Ptger4 floxed mice. We found that tumor-bearing mice lacking the $\mathrm{EP}_{4}$ receptor in the nervous system developed anorexia similar to wild-type controls (Fig. 4H). Validation of the conditional knock-out mice by qPCR analysis on hypothalami (known to harbour strong $\mathrm{EP}_{4}$ expression) confirmed that 
we successfully had removed the $\mathrm{EP}_{4}$ from the brain, with Ptger 4 mRNA levels in the brain of KO mice being less than $10^{\wedge-6}$ of those in wild-type mice $(P<0.001)$.

\section{Discussion}

The findings of the present study demonstrate that cyclooxygenases, most likely the COX-1 isoform, are involved in cancer-elicited anorexia and body weight loss, but that the development of this syndrome occurs independently of mPGES-1, $\mathrm{PGE}_{2}$ and neuronal $\mathrm{EP}_{4}$ signaling.

To identify the behavioral component that caused the reduced food intake in the present experimental situation, we firstly examined the meal pattern by computerized analyses. We found that the reduced food intake was due to a substantial reduction in meal frequency, not in meal size or duration. Tumor growth had hence no effect on the average rate at which mice consumed their meals, suggesting that mastication is not affected in this paradigm. Because meal size largely was unaffected, these data also indicate that delayed gastric emptying, often associated with anorexia and observed in some cachectic states, is unlikely to explain the suppressed food intake in this model and that mechanisms regulating meal cessation are not disarranged. The effects on meal pattern seen in the tumor-bearing mice are similar to those of elicited by substances used to mimic sickness and that reduce food intake. Hence, lithium chloride or LPS injection principally affects meal frequency and not meal size or duration (Langhans et al., 1989; West et al., 1987). However, this effect differs from that elicited by other centrally acting anorexigenic signals, such as leptin, fenfluramine, and CCK, which reduce food intake by reducing meal size and not meal frequency (Eckel et al., 1998). It also differs from that of pro-inflammatory cytokines, such as IL-1 $\beta$, which reduce both meal size and meal duration (Plata-Salaman, 1994). Therefore, the changes in meal pattern in tumorbearing mice that result in a decrease in food intake seem to occur through a specific action on 
feeding behavior, which may be related to the initiation of meals over time and that possibly also involve motivational aspects.

Being consistent with previous observations, we found that indomethacin attenuated tumor-induced anorexia and that this drug also inhibited tumor growth (Gelin et al., 1991; Sandstrom et al., 1990). It has also been demonstrated the indomethacin treatment prolongs survival in the current model, irrespective of when during the disease course treatment is undertaken (Gelin et al., 1988; Lonnroth et al., 1995). This is similar to clinical observations demonstrating that indomethacin treatment of malnourished patients with metastatic solid tumors prolongs survival (Lundholm et al., 1994).

However, it has been unclear whether the attenuated anorexia is the result of decreased tumor load or a direct effect on the brain circuitry that regulates food intake. Here we demonstrate that indomethacin given when tumor-bearing mice had developed anorexia restored appetite without affecting tumor size, indicating a direct action of indomethacin on the signaling to or in the brain. Importantly, the indomethacin treatment also maintained body mass. We further found that COX-2 inhibition had no effect on the tumor-induced anorexia. Only a weak COX-2 expression was seen in cells of the blood-brain barrier, and this was not associated with any significant increase in $\mathrm{PGE}_{2}$ levels in the CSF. These observations are different from those observed when animals are challenged with e.g. LPS or cytokines (Elander et al., 2007; Lugarini et al., 2002; Pecchi et al., 2006), and imply that increased central $\mathrm{PGE}_{2}$ levels, known to induce anorexia (Ohinata et al., 2006), are not at play in the present model. Also, it should be noted that the present tumor model, in contrast to endotoxin challenge, does not elicit increased serum levels of interleukin-1 $\beta$ or TNF $\alpha$ (Lonnroth et al., 1990). This observation fits well with the absence of increased central levels of $\mathrm{PGE}_{2}$, which is synthesized in brain endothelial cells in response to such stimuli (Cao et al., 1998; Ek et al., 2001). Furthermore, neither interleukin- $1 \beta$ or TNF $\alpha$ levels in the brain change significantly in 
this model (Wang et al., 2001), hence implying that neither peripheral nor central cytokines, which are clearly involved in inflammation-induced reduced food intake (Hellerstein et al., 1989; Tracey et al., 1988), trigger the tumor-induced anorexia.

While there was no significant change of the $\mathrm{PGE}_{2}$ level in the CSF of tumor-bearing mice, serum levels of $\mathrm{PGE}_{2}$ were greatly increased. This observation implies that $\mathrm{PGE}_{2}$ does not easily pass between blood and brain, being consistent with previous observations showing that brain parenchymal levels of peripherally injected radiolabeled $\mathrm{PGE}_{2}$ amounted to only a few percent of the obtained serum level (Eguchi et al., 1992). It also fits with the present finding that tumor-bearing mice were afebrile, being consistent with the demonstration that increased central, but not peripheral $\mathrm{PGE}_{2}$ levels, are associated with fever (Engström et al., 2012).

Our conclusion that COX-2 is not involved in cancer-induced anorexia - at least not in the present tumor model - is critically dependent on that an adequate COX-2 inhibition was achieved. The dose of parecoxib used was selected so that it extinguished lipopolysaccharideinduced fever, and was hence sufficient for inhibiting induced $\mathrm{PGE}_{2}$ production in an acute inflammatory setting. However, during chronic conditions, such as cancer, it is possible that the bioavailability of the drug could be different (Morgan et al., 2008), and this could be a potential caveat in the interpretation of the present data. However, for the synthesis of inflammatory induced $\mathrm{PGE}_{2}, \mathrm{COX}-2$ is generally coupled to mPGES-1, and similar to COX-2 inhibition, mPGES-1 deletion did not attenuate the tumor-induced anorexia, supporting the data obtained with parecoxib treatment.

The maintained anorexic response in mPGES-1 knock-out mice is in clear contrast to the report by Pecchi and colleagues (2008) that such mice did not exhibit tumor-induced anorexia and maintained their body mass. While in neither the present study or in that by Pecchi et al. (2008), there was any up-regulation of mPGES-1 within the brain or effect on 
tumor size by mPGES-1 deletion, the effect of the mPGES-1 deletion on the anorexic response thus differed. While there is no clear explanation to this discrepancy, we note that different tumor models (LLC vs. MCG 101) and different background strain of mice (DBA/1lacJ vs. C57BL/6) were used. It should also be noted that both the MCG 101 and the LLC carcinoma are syngeneic to the C57BL/6 mouse strain that was used in the present study, and not to DBA/1lacJ that was used in the Pecchi et al. (2008) study, and that the LLC carcinoma in the DBA/1lacJ strain hence may induce a different immune response than that one elicited in the syngeneic strain. Our finding that mPGES-1 deletion did not influence tumor growth is at some odds with recent reports on mPGES-1 dependent carcinogenesis (Hanaka et al., 2009; Kamei et al., 2010; Nakanishi et al., 2008). However, being in line with our findings, Elander and colleagues (2008) reported that the number and size of intestinal tumors rather increased, and not decreased, in APC ${ }^{\mathrm{Min} /}{ }^{\mathrm{mPGES}}-\mathrm{1}^{-/-}$mice (Elander et al., 2008).

Although the observations following COX-2 and mPGES-1 inhibition speaks against an involvement of induced $\mathrm{PGE}_{2}$ synthesis in tumor-induced anorexia, it was still conceivable that small amounts of $\mathrm{PGE}_{2}$ transported into the brain or released in the brain in a paracrine manner, or $\mathrm{PGE}_{2}$ binding to EP receptor expressing peripheral nerves could play a role. It is also possible that $\mathrm{PGE}_{2}$ (or other prostanoids) signal indirectly to the brain for example through peripheral inhibition of the orexigenic peptide ghrelin (Saper et al., 2012). We therefore also tested whether anorexia could be affected by neutralizing antibodies to $\mathrm{PGE}_{2}$ and whether it appeared in mice with deletion in neural cells of the $\mathrm{EP}_{4}$ receptor, which has been shown to elicit anorexia (Ohinata et al., 2006), possibly through activation of the melanocortin system (Saper et al., 2012). It should be noted that the Nestin-Cre line used in the present experiment for the conditional $\mathrm{EP}_{4}$ deletion ablates the Ptger4 not only in the brain but also in the peripheral nervous system, such as the sensory neurons of the vagus nerve 
(data not shown), known to express $\mathrm{PGE}_{2}$ receptors (Ek et al., 1998). Neither of these approaches showed any effect on the tumor-induced anorexia, indicating that $\mathrm{PGE}_{2}$ is not the prostanoid responsible for the reduced food intake. This conclusion is also supported by our previous demonstration that absence of host $\mathrm{EP}_{1}$ or $\mathrm{EP}_{3}$ receptors neither attenuates anorexia in tumor-bearing mice (Wang et al., 2005). While the $\mathrm{EP}_{2}$ receptor remains to be excluded, this is not easily accomplished in the present experimental paradigm, since the $\mathrm{EP}_{2}$ receptor is critical for tumor development. Thus mice with congenital $\mathrm{EP}_{2}$ deletion exhibit markedly attenuated tumor growth (and survive longer) compared with WT mice when implanted with syngeneic tumors (Yang et al., 2003).

While COX-2 inhibition had no effect on the tumor-induced anorexia, a positive effect on cancer-induced anorexia was seen after treatment with a COX-1 inhibitor. This is an unexpected and a novel finding considering that $\mathrm{COX}-1$ classically is not coupled to inflammation, carcinogenesis or inflammation-induced anorexia. Thus, in the Colon26 and 1483 HNSCC models respectively, a selective COX-2 inhibitor reversed weight loss without affecting tumor growth, whereas COX-1 inhibition had no effect (Davis et al., 2004). However, food intake was not affected in any of the two models over a four-day period of food intake monitoring. On the other hand, there is evidence for a role for COX-1, and not COX-2, in some tumors. For example, human and mouse ovarian cancers over-express COX1, not COX-2 (Daikoku et al., 2006; Gupta et al., 2003), and SC560, similar to aspirin (with a preference to inhibit COX-1 over COX-2), reduces the growth of ovarian tumors in mice (Daikoku et al., 2007; Daikoku et al., 2005).

Since inhibition of COX-1 delayed the onset of anorexia, but did not hinder its development, taken together with the finding that non-selective COX inhibition attenuated or reversed the anorexia, the current experiments cannot exclude that both COX-1 and COX-2 are involved in tumor-induced anorexia. It should be noted that the COX-1 inhibition reduced 
plasma $\mathrm{PGE}_{2}$-levels to sham control levels, implying that an effective dose was consumed. Thus, it is possible that COX-1 and COX-2 act in concert in an additive manner, and hence that the beneficial effects from non-selective COX inhibition is a result of inhibiting actions of both enzymes. The present results suggest that the early anorexic response is mediated by COX-1 and it may thus be speculated that the later response is mediated by both isoforms. Indeed, it has been demonstrated that COX-1 can play a role especially during the initial stages in various inflammatory responses, when COX-2 is presumably not fully upregulated (Langenbach et al., 1995). In line with this, the immediate corticosterone release seen after immune challenge with LPS is dependent on COX-1 derived prostanoids, whereas the later corticosterone response is dependent on COX-2 (Elander et al., 2010). Hence, it is possible that the COX isoforms play distinct, but temporally supplementary roles not only for the stress hormone response to inflammation but also for cancer-induced anorexia.

A question that also arises is the nature of the cellular source of COX-1. While the tumor in the present study has been reported to express COX-1 (Cahlin et al., 2000b), the expression of COX-1 in the brain has been sparsely investigated. Quite recently however, Garcia-Bueno and colleagues (2009) reported inflammation-induced COX-1 expression in brain blood vessel associated cells and parenchymal microglia, implying that these cells may be the source of COX-1 dependent prostanoid production in the brain (Garcia-Bueno et al., 2009). Because peroral administration of SC560 results in approximately the same drug concentration in the CNS as in plasma (Smith et al., 1998) the effect observed in the present study could depend on the interference with either a peripheral or central action of COX-1, or both.

Finally, it remains to be clarified which COX-1 dependent prostanoids that is involved in the tumor-induced anorexia. Little is known about other prostanoids besides $\mathrm{PGE}_{2}$ in relation to anorexia, and much less, if anything, has been done so far in relation to tumor- 
induced anorexia. Examination of the gene expression of terminal prostaglandin synthases in the present study showed very discrete changes in tumor bearing mice, with the notable exception of lipocalin-type PGD-synthase that was increased by $45 \%$. This is somewhat surprising considering that $\mathrm{PGD}_{2}$ has been reported to stimulate appetite (Ohinata et al., 2006; Pourtau et al., 2011). Of the prostaglandins that have been reported to have anorexigenic properties $\left(\mathrm{PGE}_{1}, \mathrm{PGF}_{1 \alpha}, \mathrm{PGF}_{2 \alpha}, \mathrm{PGA}_{1}\right.$, and $\mathrm{PGB}_{1}$; Scaramuzzi et al., 1971), $\mathrm{PGF}_{2 \alpha}$ appears the most studied (Doggett and Jawaharlal, 1977; Lal, 1984). However, two observations argue against a role for $\mathrm{PGF}_{2 \alpha}$ in cancer-induced anorexia. Firstly, the appetite suppressing effect of $\mathrm{PGF}_{2 \alpha}$ is short-lived (possibly lasting $\sim 180 \mathrm{~min}$ ), especially when delivered peripherally (1530 min; (Doggett and Jawaharlal, 1977), and, secondly, $\mathrm{PGF}_{2 \alpha}$ activates muscle protein synthesis (Horsley and Pavlath, 2003), which is quite different to the muscle wasting that is characteristic for cachexia.

\section{Acknowledgements}

Supported by grants from the Swedish Cancer Foundation, the Swedish Research Council, the Swedish Brain Foundation, and Konung Gustaf V:s 80-årsfond.

\section{References}

Axelsson, H., Lonnroth, C., Wang, W., Svanberg, E., Lundholm, K., 2005. Cyclooxygenase inhibition in early onset of tumor growth and related angiogenesis evaluated in EP1 and EP3 knockout tumor-bearing mice. Angiogenesis 8, 339-348.

Bosaeus, I., Daneryd, P., Svanberg, E., Lundholm, K., 2001. Dietary intake and resting energy expenditure in relation to weight loss in unselected cancer patients. Int. J. Cancer 93, 380383. 
Brown, J.R., DuBois, R.N., 2005. COX-2: A Molecular Target for Colorectal Cancer Prevention. J. Clin. Oncol. 23, 2840-2855.

Cahlin, C., Gelin, J., Andersson, M., Lonnroth, C., Lundholm, K., 2005. The effects of nonselective, preferential-selective and selective COX-inhibitors on the growth of experimental and human tumors in mice related to prostanoid receptors. Int. J. Oncol. 27, 913-923.

Cahlin, C., Gelin, J., Delbro, D., Lonnroth, C., Doi, C., Lundholm, K., 2000a. Effect of cyclooxygenase and nitric oxide synthase inhibitors on tumor growth in mouse tumor models with and without cancer cachexia related to prostanoids. Cancer Res. 60, $1742-$ 1749.

Cahlin, C., Korner, A., Axelsson, H., Wang, W., Lundholm, K., Svanberg, E., 2000b. Experimental cancer cachexia: the role of host-derived cytokines interleukin (IL)-6, IL-12, interferon-gamma, and tumor necrosis factor alpha evaluated in gene knockout, tumorbearing mice on C57 Bl background and eicosanoid-dependent cachexia. Cancer Res. 60, 5488-5493.

Cao, C., Matsumura, K., Yamagata, K., Watanabe, Y., 1998. Cyclooxygenase-2 is induced in brain blood vessels during fever evoked by peripheral or central administration of tumor necrosis factor. Brain Res. Mol. Brain Res. 56, 45-56.

Daikoku, T., Tranguch, S., Chakrabarty, A., Wang, D., Khabele, D., Orsulic, S., Morrow, J.D., Dubois, R.N., Dey, S.K., 2007. Extracellular signal-regulated kinase is a target of cyclooxygenase-1-peroxisome proliferator-activated receptor-delta signaling in epithelial ovarian cancer. Cancer Res 67, 5285-5292.

Daikoku, T., Tranguch, S., Trofimova, I.N., Dinulescu, D.M., Jacks, T., Nikitin, A.Y., Connolly, D.C., Dey, S.K., 2006. Cyclooxygenase-1 is overexpressed in multiple 
genetically engineered mouse models of epithelial ovarian cancer. Cancer Res 66, 25272531.

Daikoku, T., Wang, D., Tranguch, S., Morrow, J.D., Orsulic, S., DuBois, R.N., Dey, S.K., 2005. Cyclooxygenase- 1 is a potential target for prevention and treatment of ovarian epithelial cancer. Cancer Res. 65, 3735-3744.

Doggett, N.S., Jawaharlal, K., 1977. Some observations on the anorectic activity of prostaglandin F2alpha. Br J Pharmacol 60, 409-415.

Eckel, L.A., Langhans, W., Kahler, A., Campfield, L.A., Smith, F.J., Geary, N., 1998. Chronic administration of OB protein decreases food intake by selectively reducing meal size in female rats. Am. J. Physiol. 275, R186-193.

Eguchi, N., Kaneko, T., Urade, Y., Hayashi, H., Hayaishi, O., 1992. Permeability of brain structures and other peripheral tissues to prostaglandins D2, E2 and F2 alpha in rats. J. Pharmacol. Exp. Ther. 262, 1110-1120.

Ek, M., Engblom, D., Saha, S., Blomqvist, A., Jakobsson, P.J., Ericsson-Dahlstrand, A., 2001. Inflammatory response: pathway across the blood-brain barrier. Nature 410, 430-431.

Ek, M., Kurosawa, M., Lundeberg, T., Ericsson, A., 1998. Activation of vagal afferents after intravenous injection of interleukin-1beta: role of endogenous prostaglandins. J. Neurosci. $18,9471-9479$.

Elander, L., Engstrom, L., Hallbeck, M., Blomqvist, A., 2007. IL-1beta and LPS induce anorexia by distinct mechanisms differentially dependent on microsomal prostaglandin $\mathrm{E}$ synthase-1. Am. J. Physiol. Regul. Integr. Comp. Physiol. 292, R258-267.

Elander, L., Ruud, J., Korotkova, M., Jakobsson, P.J., Blomqvist, A., 2010. Cyclooxygenase1 mediates the immediate corticosterone response to peripheral immune challenge induced by lipopolysaccharide. Neurosci. Lett. 470, 10-12. 
Elander, N., Ungerback, J., Olsson, H., Uematsu, S., Akira, S., Soderkvist, P., 2008. Genetic deletion of mPGES-1 accelerates intestinal tumorigenesis in APC(Min/+) mice. Biochem. Biophys. Res. Commun. 372, 249-253.

Engblom, D., Saha, S., Engstrom, L., Westman, M., Audoly, L.P., Jakobsson, P.J., Blomqvist, A., 2003. Microsomal prostaglandin E synthase-1 is the central switch during immuneinduced pyresis. Nat. Neurosci. 6, 1137-1138.

Engström, L., Ruud, J., Eskilsson, A., Larsson, A., Mackerlova, L., Kugelberg, U., Qian, H., Vasilache, A.M., Larsson, P., Engblom, D., Sigvardsson, M., Jönsson, J.-I., Blomqvist, A., 2012. Lipopolysaccharide-Induced Fever Depends on Prostaglandin E2 Production Specifically in Brain Endothelial Cells. Endocrinology 153, 4849-4861.

Fearon, K., Strasser, F., Anker, S.D., Bosaeus, I., Bruera, E., Fainsinger, R.L., Jatoi, A., Loprinzi, C., MacDonald, N., Mantovani, G., Davis, M., Muscaritoli, M., Ottery, F., Radbruch, L., Ravasco, P., Walsh, D., Wilcock, A., Kaasa, S., Baracos, V.E., 2011. Definition and classification of cancer cachexia: an international consensus. Lancet Oncol. $12,489-495$.

Garcia-Bueno, B., Serrats, J., Sawchenko, P.E., 2009. Cerebrovascular cyclooxygenase-1 expression, regulation, and role in hypothalamic-pituitary-adrenal axis activation by inflammatory stimuli. J. Neurosci. 29, 12970-12981.

Gelin, J., Andersson, C., Lundholm, K., 1991. Effects of indomethacin, cytokines, and cyclosporin A on tumor growth and the subsequent development of cancer cachexia. Cancer Res 51, 880-885.

Gelin, J., Moldawer, L.L., Lonnroth, C., deMan, P., Svanborg-Eden, C., Lowry, S.F., Lundholm, K.G., 1988. Appearance of hybridoma growth factor/interleukin-6 in the serum 
of mice bearing a methylcholanthrene-induced sarcoma. Biochem. Biophys. Res. Commun. 157, 575-579.

Gupta, R.A., Tejada, L.V., Tong, B.J., Das, S.K., Morrow, J.D., Dey, S.K., DuBois, R.N., 2003. Cyclooxygenase-1 is overexpressed and promotes angiogenic growth factor production in ovarian cancer. Cancer Res. 63, 906-911.

Hanaka, H., Pawelzik, S.C., Johnsen, J.I., Rakonjac, M., Terawaki, K., Rasmuson, A., Sveinbjornsson, B., Schumacher, M.C., Hamberg, M., Samuelsson, B., Jakobsson, P.J., Kogner, P., Radmark, O., 2009. Microsomal prostaglandin E synthase 1 determines tumor growth in vivo of prostate and lung cancer cells. Proc. Natl. Acad. Sci. U S A 106, 1875718762.

Hellerstein, M.K., Meydani, S.N., Meydani, M., Wu, K., Dinarello, C.A., 1989. Interleukin-1induced anorexia in the rat. Influence of prostaglandins. J. Clin. Invest. 84, 228-235.

Horsley, V., Pavlath, G.K., 2003. Prostaglandin F2 $\alpha$ stimulates growth of skeletal muscle cells via an NFATC2-dependent pathway. J. Cell Biol. 161, 111-118.

Kamei, D., Murakami, M., Sasaki, Y., Nakatani, Y., Majima, M., Ishikawa, Y., Ishii, T., Uematsu, S., Akira, S., Hara, S., Kudo, I., 2010. Microsomal prostaglandin E synthase-1 in both cancer cells and hosts contributes to tumour growth, invasion and metastasis. Biochem. J. 425, 361-371.

Lal, J., 1984. Possible role of prostaglandins in the regulation of food intake in the newborn rat. Arch. Int. Pharmacodyn. Ther. 272, 140-149.

Langenbach, R., Morham, S.G., Tiano, H.F., Loftin, C.D., Ghanayem, B.I., Chulada, P.C., Mahler, J.F., Lee, C.A., Goulding, E.H., Kluckman, K.D., Kim, H.S., Smithies, O., 1995. Prostaglandin synthase 1 gene disruption in mice reduces arachidonic acid-induced inflammation and indomethacin-induced gastric ulceration. Cell 83, 483-492. 
Langhans, W., Harlacher, R., Scharrer, E., 1989. Verapamil and indomethacin attenuate endotoxin-induced anorexia. Physiol. Behav. 46, 535-539.

Levine, A.S., Morley, J.E., 1981. The effect of prostaglandins (PGE2 and PGF2 alpha) on food intake in rats. Pharmacol. Biochem. Behav. 15, 735-738.

Lonnroth, C., Moldawer, L.L., Gelin, J., Kindblom, L., Sherry, B., Lundholm, K., 1990. Tumor necrosis factor-alpha and interleukin-1 alpha production in cachectic, tumorbearing mice. Int. J. Cancer 46, 889-896.

Lonnroth, C., Svaninger, G., Gelin, J., Cahlin, C., Iresjo, B., Cvetkovska, E., Edstrom, S., Andersson, M., Svanberg, E., Lundholm, K., 1995. Effects related to indomethacin prolonged survival and decreased tumor-growth in a mouse-tumor model with cytokine dependent cancer cachexia. Int. J. Oncol. 7, 1405-1413.

Lugarini, F., Hrupka, B.J., Schwartz, G.J., Plata-Salaman, C.R., Langhans, W., 2002. A role for cyclooxygenase-2 in lipopolysaccharide-induced anorexia in rats. Am. J. Physiol. Regul. Integr. Comp. Physiol. 283, R862-868.

Lundholm, K., Edstrom, S., Ekman, L., Karlberg, I., Bylund, A.C., Schersten, T., 1978. A comparative study of the influence of malignant tumor on host metabolism in mice and man: evaluation of an experimental model. Cancer 42, 453-461.

Lundholm, K., Gelin, J., Hyltander, A., Lonnroth, C., Sandstrom, R., Svaninger, G., Korner, U., Gulich, M., Karrefors, I., Norli, B., et al., 1994. Anti-inflammatory treatment may prolong survival in undernourished patients with metastatic solid tumors. Cancer Res. 54, $5602-5606$.

Mnich, S.J., Veenhuizen, A.W., Monahan, J.B., Sheehan, K.C., Lynch, K.R., Isakson, P.C., Portanova, J.P., 1995. Characterization of a monoclonal antibody that neutralizes the activity of prostaglandin E2. J. Immunol. 155, 4437-4444. 
Morgan, E.T., Goralski, K.B., Piquette-Miller, M., Renton, K.W., Robertson, G.R., Chaluvadi, M.R., Charles, K.A., Clarke, S.J., Kacevska, M., Liddle, C., Richardson, T.A., Sharma, R., Sinal, C.J., 2008. Regulation of drug-metabolizing enzymes and transporters in infection, inflammation, and cancer. Drug. Metab. Dispos. 36, 205-216.

Murakami, M., Kudo, I., 2006. Prostaglandin E synthase: a novel drug targetfor inflammation and cancer. Curr. Pharm. Des. 12, 943-954.

Nakanishi, M., Montrose, D.C., Clark, P., Nambiar, P.R., Belinsky, G.S., Claffey, K.P., Xu, D., Rosenberg, D.W., 2008. Genetic deletion of mPGES-1 suppresses intestinal tumorigenesis. Cancer Res. 68, 3251-3259.

Ohinata, K., Suetsugu, K., Fujiwara, Y., Yoshikawa, M., 2006. Activation of prostaglandin E receptor EP4 subtype suppresses food intake in mice. Prostag. Oth. Lipid M. 81, 31-36.

Pecchi, E., Dallaporta, M., Thirion, S., Salvat, C., Berenbaum, F., Jean, A., Troadec, J.D., 2006. Involvement of central microsomal prostaglandin E synthase-1 in IL-1beta-induced anorexia. Physiol. Genomics 25, 485-492.

Plata-Salaman, C.R., 1994. Meal patterns in response to the intracerebroventricular administration of interleukin-1 beta in rats. Physiol. Behav. 55, 727-733.

Portanova, J.P., Zhang, Y., Anderson, G.D., Hauser, S.D., Masferrer, J.L., Seibert, K., Gregory, S.A., Isakson, P.C., 1996. Selective neutralization of prostaglandin E2 blocks inflammation, hyperalgesia, and interleukin 6 production in vivo. J. Exp. Med. 184, 883891.

Pourtau, L., Leemburg, S., Roux, P., Leste-Lasserre, T., Costaglioli, P., Garbay, B., Drutel, G., Konsman, J.P., 2011. Hormonal, hypothalamic and striatal responses to reduced body weight gain are attenuated in anorectic rats bearing small tumors. Brain Behav. Immun. 25, 777-786. 
Ruud, J., Backhed, F., Engblom, D., Blomqvist, A., 2010. Deletion of the gene encoding MyD88 protects from anorexia in a mouse tumor model. Brain Behav. Immun. 24, 554557.

Ruud, J., Blomqvist, A., 2007. Identification of rat brainstem neuronal structures activated during cancer-induced anorexia. J. Comp. Neurol. 504, 275-286.

Samuelsson, B., Morgenstern, R., Jakobsson, P.J., 2007. Membrane prostaglandin E synthase1: a novel therapeutic target. Pharmacol. Rev. 59, 207-224.

Sandstrom, R., Gelin, J., Lundholm, K., 1990. The effect of indomethacin on food and water intake, motor activity and survival in tumour-bearing rats. Eur. J. Cancer 26, 811-814.

Saper, C.B., Romanovsky, A.A., Scammell, T.E., 2012. Neural circuitry engaged by prostaglandins during the sickness syndrome. Nat. Neurosci. 15, 1088-1095.

Scaramuzzi, O.E., Baile, C.A., Mayer, J., 1971. Prostaglandins and food intake of rats. Experientia 27, 256-257.

Schneider, A., Guan, Y., Zhang, Y., Magnuson, M.A., Pettepher, C., Loftin, C.D., Langenbach, R., Breyer, R.M., Breyer, M.D., 2004. Generation of a conditional allele of the mouse prostaglandin EP4 receptor. Genesis 40, 7-14.

Smith, C.J., Zhang, Y., Koboldt, C.M., Muhammad, J., Zweifel, B.S., Shaffer, A., Talley, J.J., Masferrer, J.L., Seibert, K., Isakson, P.C., 1998. Pharmacological analysis of cyclooxygenase-1 in inflammation. Proc. Natl. Acad. Sci. U S A 95, 13313-13318.

Steinbach, G., Lynch, P.M., Phillips, R.K.S., Wallace, M.H., Hawk, E., Gordon, G.B., Wakabayashi, N., Saunders, B., Shen, Y., Fujimura, T., Su, L.-K., Levin, B., Godio, L., Patterson, S., Rodriguez-Bigas, M.A., Jester, S.L., King, K.L., Schumacher, M., Abbruzzese, J., DuBois, R.N., Hittelman, W.N., Zimmerman, S., Sherman, J.W., Kelloff, 
G., 2000. The Effect of Celecoxib, a Cyclooxygenase-2 Inhibitor, in Familial Adenomatous Polyposis. New Engl. J. Med. 342, 1946-1952.

Tisdale, M.J., 2010. Cancer cachexia. Curr. Opin. Gastroenterol. 26, 146-151.

Tracey, K.J., Wei, H., Manogue, K.R., Fong, Y., Hesse, D.G., Nguyen, H.T., Kuo, G.C., Beutler, B., Cotran, R.S., Cerami, A., 1988. Cachectin/tumor necrosis factor induces cachexia, anemia, and inflammation. J. Exp. Med. 167, 1211-1227.

Trebino, C.E., Stock, J.L., Gibbons, C.P., Naiman, B.M., Wachtmann, T.S., Umland, J.P., Pandher, K., Lapointe, J.M., Saha, S., Roach, M.L., Carter, D., Thomas, N.A., Durtschi, B.A., McNeish, J.D., Hambor, J.E., Jakobsson, P.J., Carty, T.J., Perez, J.R., Audoly, L.P., 2003. Impaired inflammatory and pain responses in mice lacking an inducible prostaglandin E synthase. Proc. Natl. Acad. Sci. U S A 100, 9044-9049.

Tronche, F., Kellendonk, C., Kretz, O., Gass, P., Anlag, K., Orban, P.C., Bock, R., Klein, R., Schutz, G., 1999. Disruption of the glucocorticoid receptor gene in the nervous system results in reduced anxiety. Nat. Genet. 23, 99-103.

Wang, W., Andersson, M., Lonnroth, C., Svanberg, E., Lundholm, K., 2005. Prostaglandin E and prostacyclin receptor expression in tumor and host tissues from MCG 101-bearing mice: a model with prostanoid-related cachexia. Int. J. Cancer 115, 582-590.

Wang, W., Lonnroth, C., Svanberg, E., Lundholm, K., 2001. Cytokine and cyclooxygenase-2 protein in brain areas of tumor-bearing mice with prostanoid-related anorexia. Cancer Res. $61,4707-4715$.

West, D.B., Greenwood, M.R., Marshall, K.A., Woods, S.C., 1987. Lithium chloride, cholecystokinin and meal patterns: evidence that cholecystokinin suppresses meal size in rats without causing malaise. Appetite 8, 221-227. 
Yang, L., Yamagata, N., Yadav, R., Brandon, S., Courtney, R.L., Morrow, J.D., Shyr, Y., Boothby, M., Joyce, S., Carbone, D.P., Breyer, R.M., 2003. Cancer-associated immunodeficiency and dendritic cell abnormalities mediated by the prostaglandin EP2 receptor. The Journal of Clinical Investigation 111, 727-735.

Zhang, Y., Shaffer, A., Portanova, J., Seibert, K., Isakson, P.C., 1997. Inhibition of cyclooxygenase-2 rapidly reverses inflammatory hyperalgesia and prostaglandin E2 production. J. Pharmacol. Exp. Ther. 283, 1069-1075. 
Figure legends

A

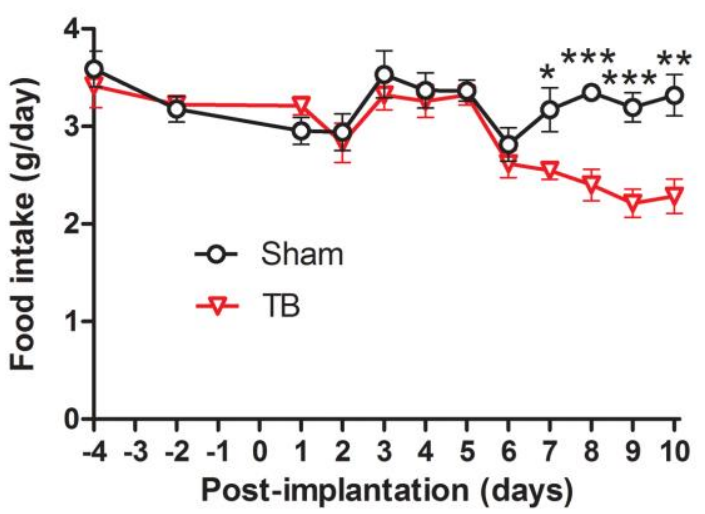

B

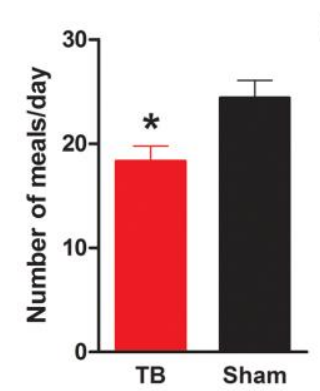

F
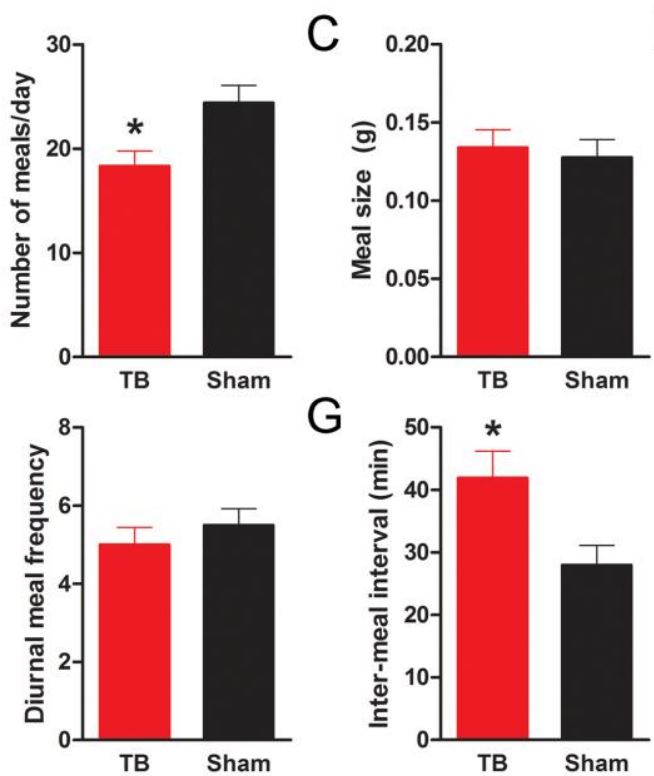

$\mathrm{G}$

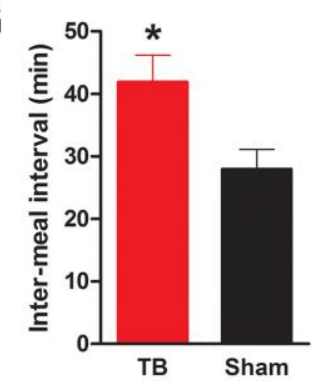

$\mathrm{H}$
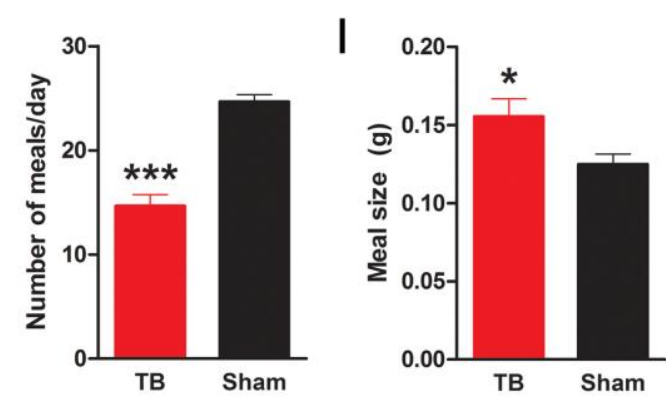

L ธิ ${ }^{500}$

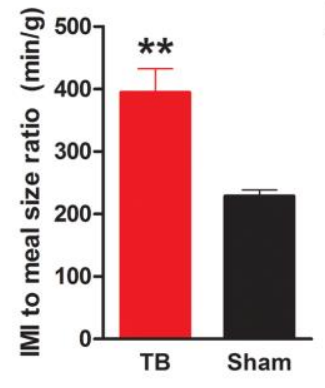

M

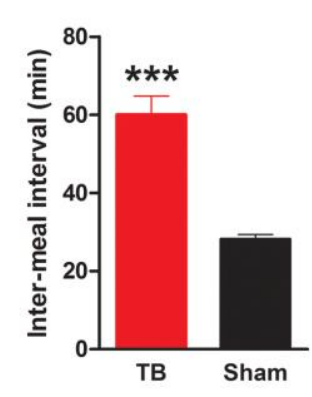

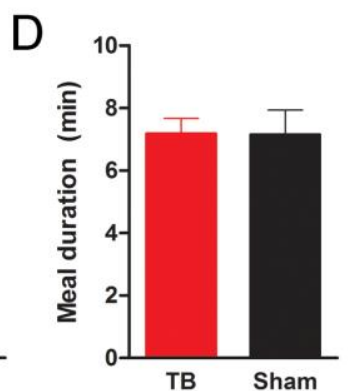

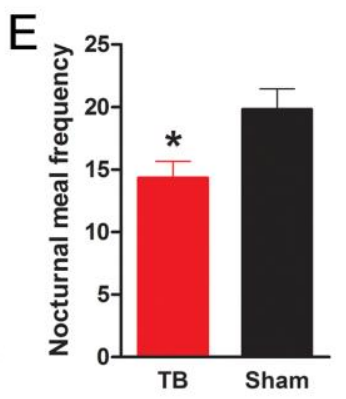

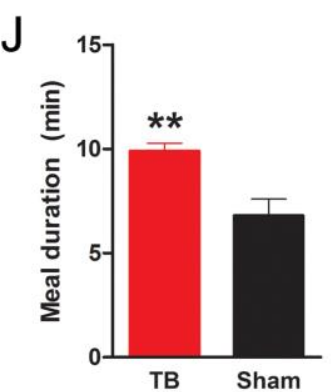

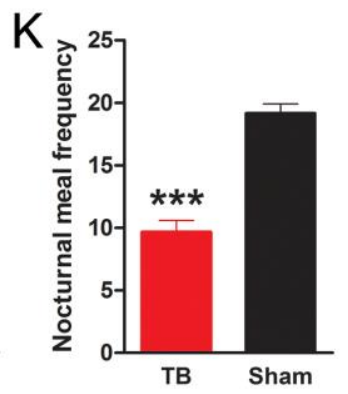

Day 10

Figure 1 
Figure 1. Effect of tumor implantation on food consumption. A, Food intake in shamimplanted (Sham) and tumor-bearing (TB) mice. B-G, Feeding parameters at anorexia onset (day 7 after tumor implantation). H-M, Feeding parameters at established anorexia (day 10 after tumor implantation). ${ }^{*} P<0.05, * * P<0.01$, and $* * * P<0.001$ between tumor-bearing and sham-implanted mice. $n=6$ in each group. Error bars show SEM. 
A

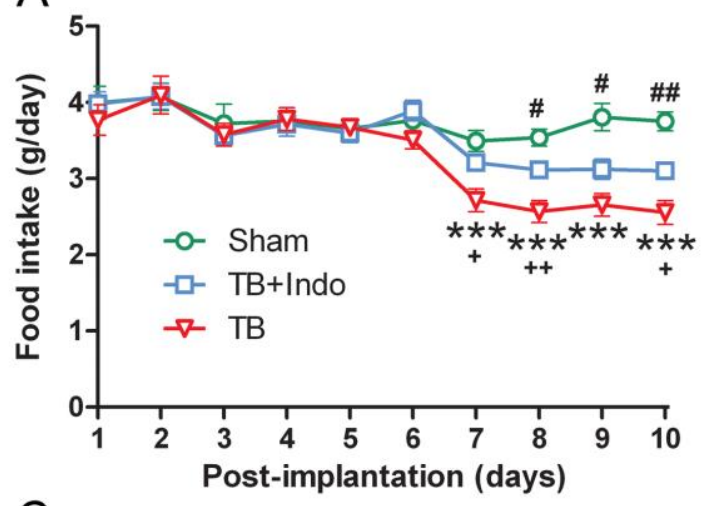

C

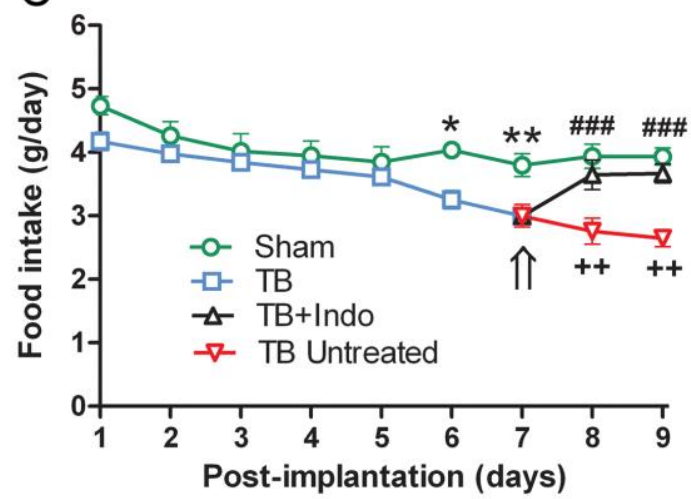

E

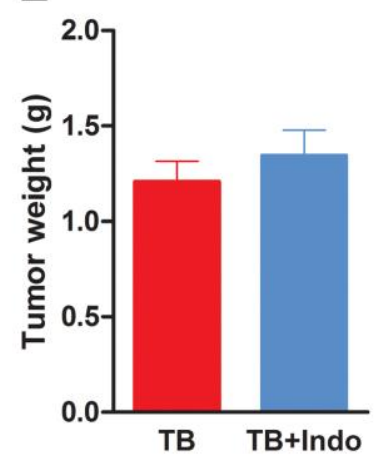

B
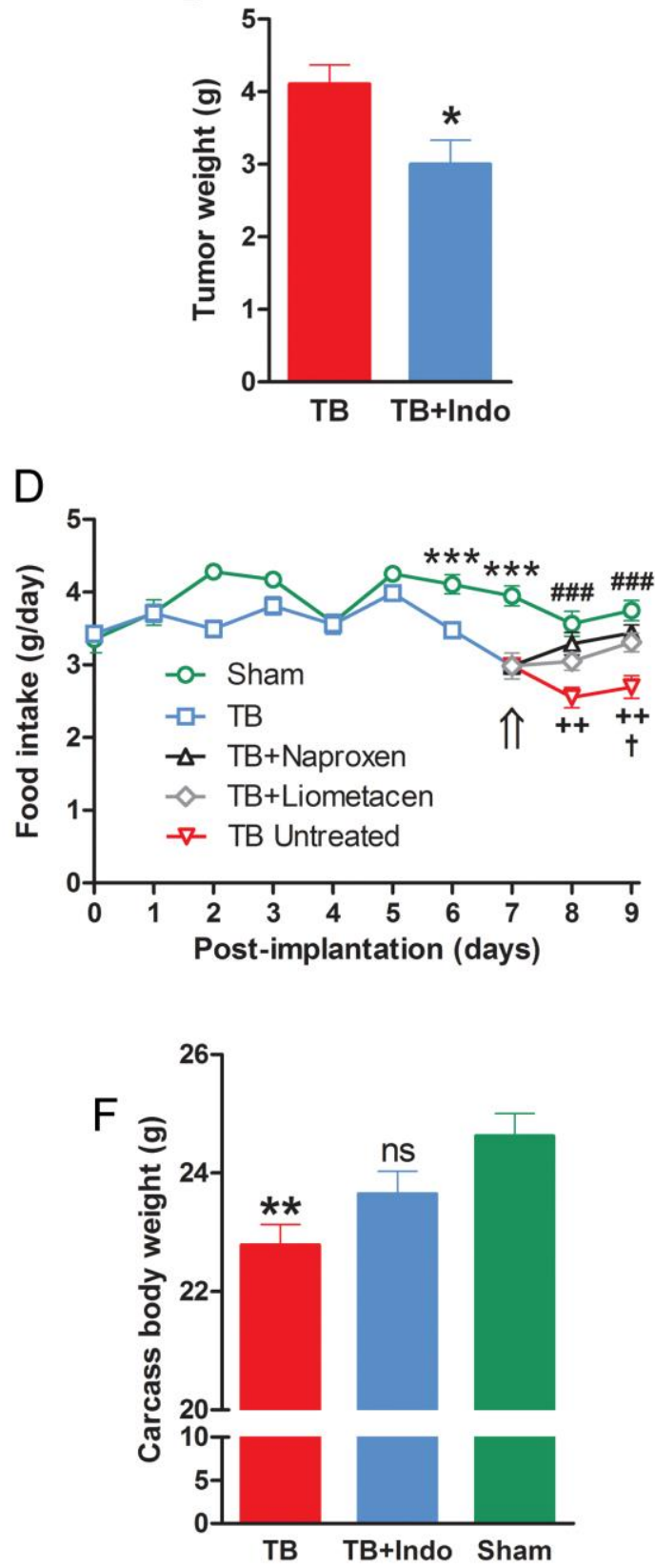

Figure 2 
Figure 2. Effects of non-selective COX-inhibition. A, Food intake in sham-implanted mice (Sham), tumor-bearing mice continuously treated with indomethacin $(\mathrm{TB}+\mathrm{Indo})$, and untreated tumor-bearing mice (TB). *** $P<0.001$ between untreated tumor-bearing mice and sham-implanted mice. $+P<0.05$, and $++P<0.01$ between indomethacin-treated and untreated tumor-bearing mice. \# $P<0.05$ and \#\# $P<0.01$ between indomethacin-treated tumor-bearing mice and sham-implanted mice. $n=10-12$ in each group. $\mathbf{B}$, Tumor weight 10 days post-implantation in indomethacin-treated or untreated tumor-bearing mice. $n=10-12$. * $P<0.05$ between the two groups. C, Effect on food intake of indomethacin given at two consecutive days of anorexia (day 7 after tumor-implantation; arrow). * $P<0.05$, and $* * P<$ 0.01 between tumor-bearing mice before treatment $(n=14)$ and sham-implanted mice $(n=7)$. $++P<0.01$ between indomethacin-treated $(n=7)$ and untreated tumor-bearing mice $(n=7)$. \#\#\# $P<0.001$ between untreated tumor-bearing mice and sham-implanted mice. $\mathbf{D}$, Effect on food intake of naproxen or Liometacen ${ }^{\circledR}$ given day 7 (arrow). $* * * P<0.001$ between tumorbearing $(n=10)$ and sham-implanted mice $(n=10)$ before treatment. $++P<0.01$ between naproxen-treated $(n=10)$ and untreated tumor-bearing mice $(n=10) . \dagger P<0.05$ between Liometacen-treated tumor-bearing mice $(n=10)$ and untreated tumor-bearing mice. \#\#\# $P<$ 0.001 between untreated tumor-bearing mice and sham-implanted mice. E, Tumor weight at day 9 in untreated tumor-bearing mice (TB) and in tumor-bearing mice treated with indomethacin (TB+Indo) from day 7 ( $n=7$ in each group). $\mathbf{F}$, carcass body weight at day 9 in untreated tumor-bearing mice (TB), tumor-bearing mice treated with indomethacin from day 7 (TB+Indo), and sham-implanted mice (Sham). ** $P<0.01$ between tumor-bearing and sham-implanted mice. ns, not statisically significant compared with sham-implanted mice. $n=$ 7 in each group. Error bars show SEM. Data on food intake in indomethacin-treated non tumor-bearing mice are given in Supplementary Figure 1A. 

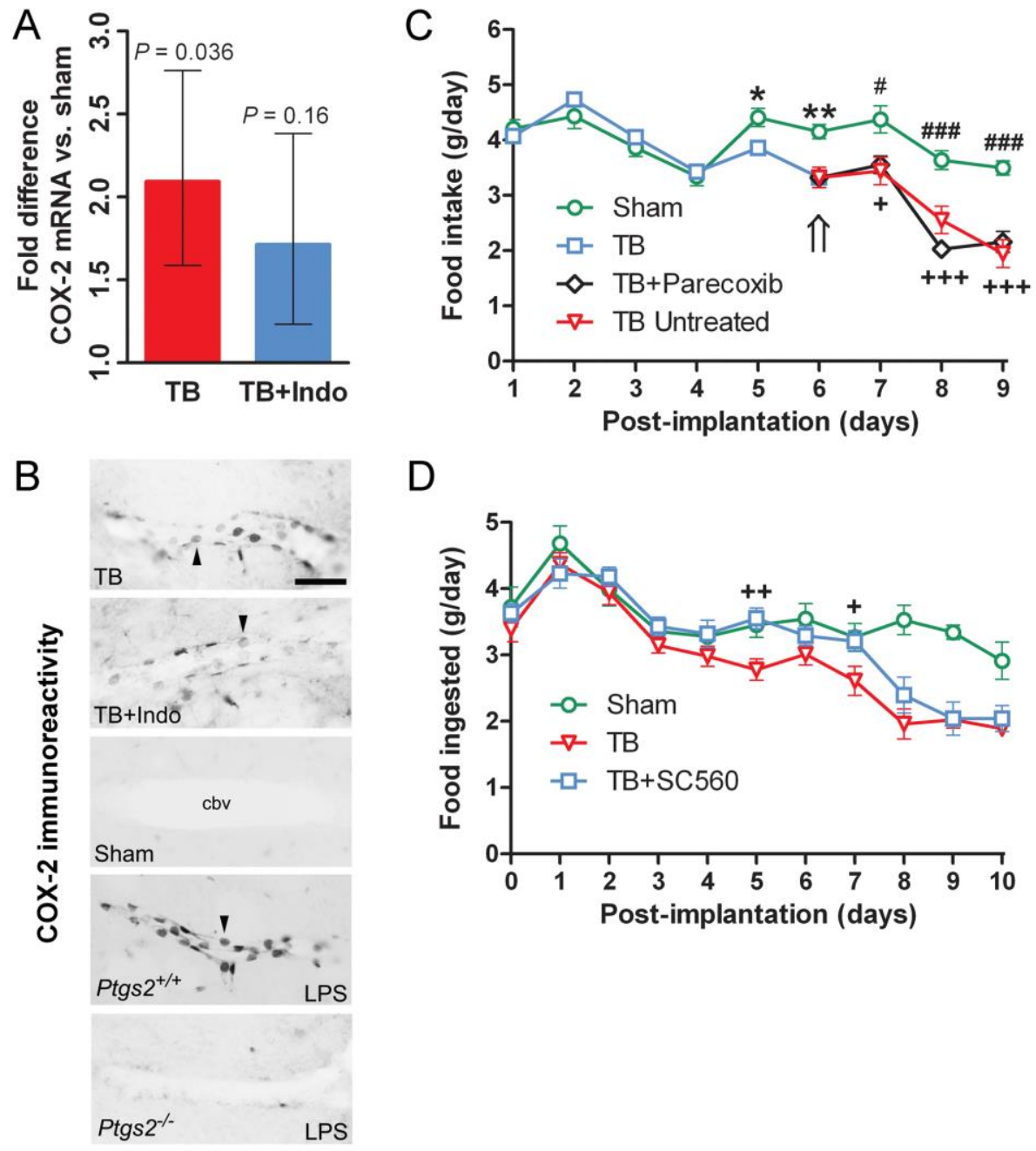

D

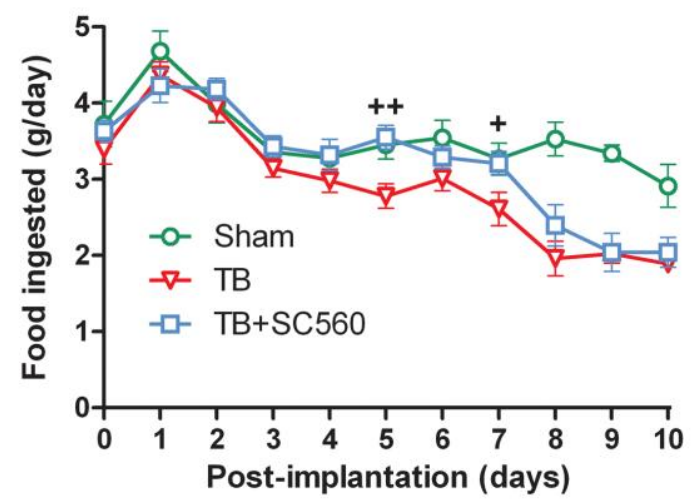

Figure 3

Figure 3. Selective cyclooxygenase expression and effect on food intake in tumor-bearing mice. A. Induced expression of COX-2 in the hypothalamus of tumor-bearing mice (TB) and 
tumor-bearing mice treated with indomethacin (TB+Indo). $P$-values compared with shamimplanted mice. $n=7$ in each group. B, COX-2 expression in cells (arrowheads) associated to the cerebral blood vessels (cbv) in tumor-bearing mice. Lower panel shows absence of labeling in COX-2 KO mice (Ptgs $2^{-/-}$) treated with lipopolysaccharide (LPS), demonstrating antibody specificity. Scale bar $=50 \mu \mathrm{m}$. C, Food intake in sham-implanted mice, and tumorbearing mice with/without treatment with parecoxib. $* P<0.05$ and $* * P<0.01$ between sham-implanted mice $(n=8)$ and tumor-bearing mice before treatment $(n=16) .+P<0.05$ and $+++P<0.001$ between parecoxib-treated tumor-bearing mice and sham-implanted mice ( $n=8$ in each group). \# $P<0.05$ and \#\#\# $P<0.001$ between untreated tumor-bearing mice and sham-implanted mice ( $n=8$ in each group). Treatment was started day 6 (arrow) with $100 \mathrm{mg} / \mathrm{kg}$ body weight (given through the drinking water), followed day 7 by $150 \mathrm{mg} / \mathrm{kg}$ body weight, and finally day 8 with $10 \mathrm{mg} / \mathrm{kg}$ body weight i.p. given at 6 p.m. and 12 p.m. D, Food intake in sham-implanted mice, and untreated and SC560-treated tumor-bearing mice. + $P<0.05$, and $++P<0.01$ between SC560 treated and untreated tumor-bearing mice. $n=8-10$ in each group. Error bars show SEM. Data on food intake in parecoxib- and SC560-treated non tumor-bearing mice are given in Supplementary Figure 1A. 

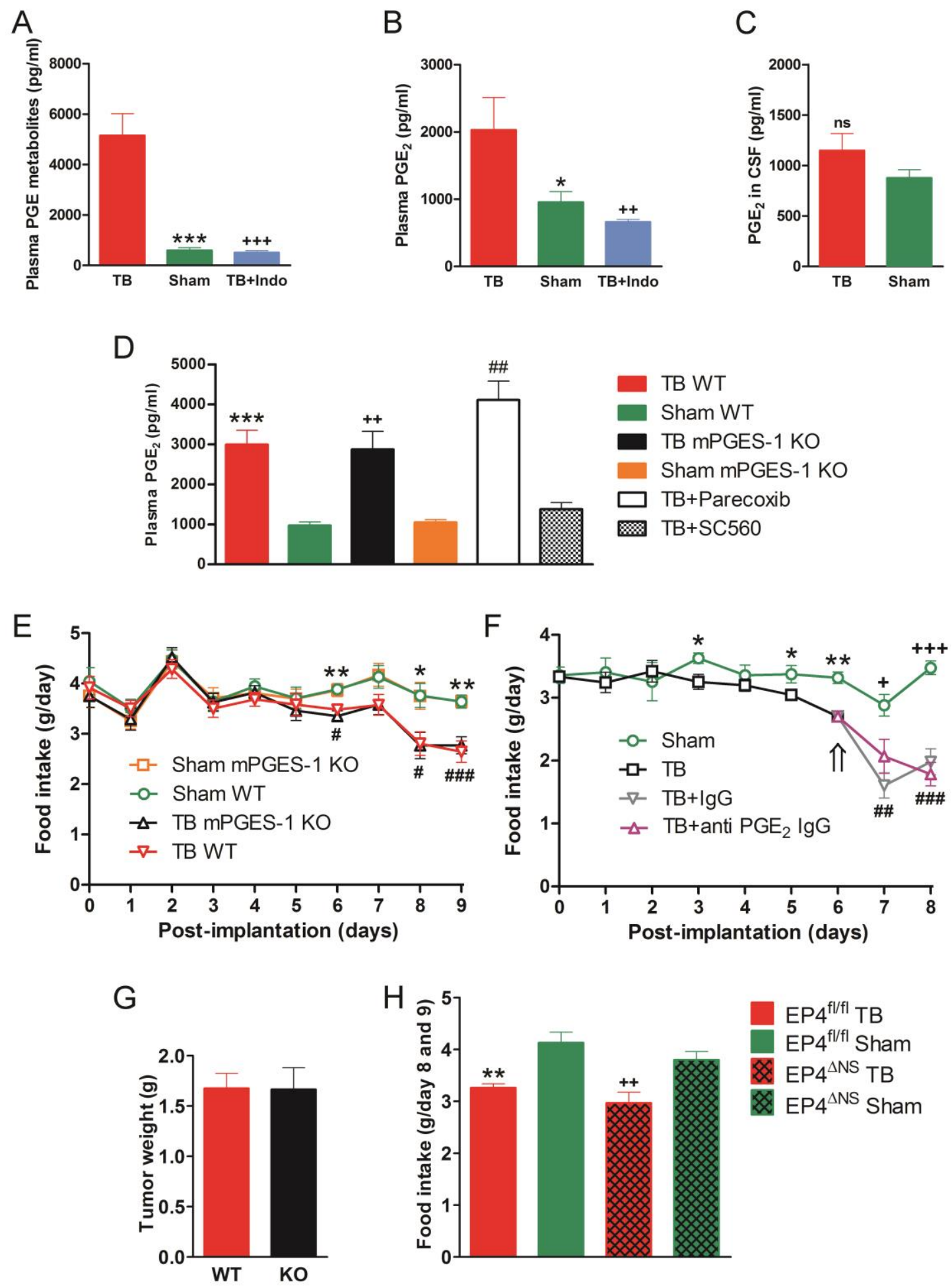

Figure 4

Figure 4. Role of $\mathrm{PGE}_{2}$ in tumor-induced anorexia. $\mathbf{A}, \mathrm{PGE}_{2}$ metabolites, and $\mathbf{B}, \mathrm{PGE}_{2}$ in plasma of sham-implanted mice (Sham), and in untreated (TB) and indomethacin treated 
tumor-bearing mice (TB+Indo). $* P<0.05 ;++P<0.01$; and $* * *$ and $+++P<0.001$ vs. untreated tumor-bearing mice. $n=8$ in each group. $\mathrm{C}, \mathrm{PGE}_{2}$ levels in cerebrospinal fluid. $n=$ 6-7 in each group. $n s=$ not significant. $\mathbf{D}, \mathrm{PGE}_{2}$ levels in plasma in sham-implanted $(n=10$ in both groups), tumor-bearing WT $(n=16)$, and mPGES-1 KO $(n=15)$ mice, and in mice treated with parecoxib $(n=3)$ or SC560 $(n=8)$. *** $P<0.001$ and $++P<0.01$ between tumor-bearing WT and KO mice and sham-implanted mice. \#\# $P<0.01$ between parecoxibtreated tumor-bearing mice and sham-implanted WT mice and tumor-bearing SC560-treated mice. E, Food intake in sham-implanted and tumor-bearing wild-type (WT) and mPGES-1 KO mice. $* P<0.05$, and $* * P<0.01$, between tumor-bearing and sham-implanted KO mice. $\# P<0.05$, and \#\#\# $P<0.001$ between tumor-bearing and sham-implanted WT mice. $n=16$ in each group. F, Food intake in sham-implanted mice $(n=10)$, and tumor-bearing mice $(n=$ 20) before and after treatment (arrow) with a monoclonal antibody against $\mathrm{PGE}_{2}$ (2B5) or a matching control IgG antibody (MOPC21). $* P<0.05$, and $* * P<0.01$ between tumorbearing and sham-implanted mice before treatment. $+P<0.05$, and $+++P<0.001$ between anti-PGE 2 treated tumor-bearing mice and sham-implanted mice. \#\# $P<0.01$, and \#\#\# $P<$ 0.001 between IgG-treated tumor-bearing and sham-implanted mice. G, Tumor weight in mPGES-1 knockout (KO) and wild-type (WT) mice. $n=16$ in each group. H, Food intake in sham-implanted and tumor-bearing wild-type mice (fl/fl) and mice with $\mathrm{EP}_{4}$-deletion in the nervous system $(\Delta \mathrm{NS}) 8$ and 9 days after tumor implantation. $n=7-8$ in each group. $* * P=$ 0.01 , and $++P<0.01$ between tumor-bearing mice and sham-implanted mice. Error bars show SEM. Data on food intake in 2B5- or MOPC21-treated non tumor-bearing mice are given in Supplementary Figure 1B. 

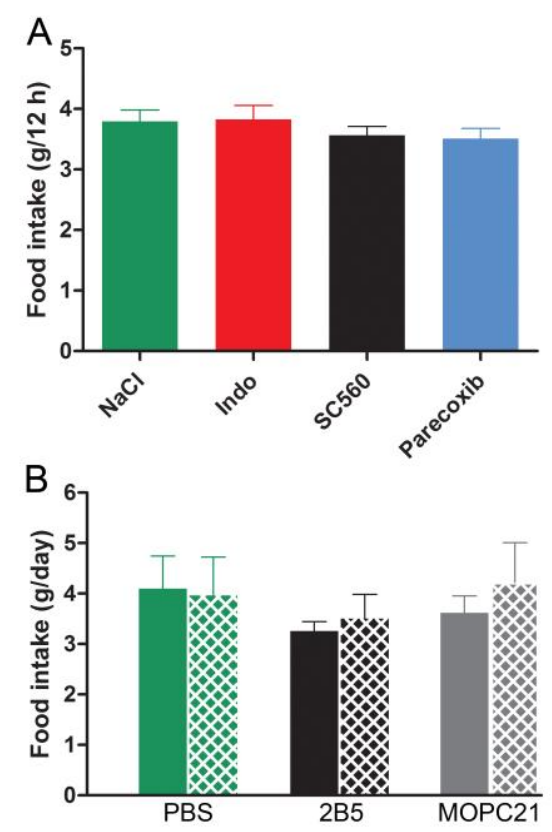

Supplementary Figure 1. A. No effect of cyclooxygenase inhibition on normal food intake. Food intake was monitored during the $12 \mathrm{~h}$ dark period in normal mice injected intraperitoneally with saline solution, indomethacin, or parecoxib, or given SC560 as gavage, in the same doses as used in the experiments shown in Figs 2 and 3. Drugs were administered $1 \mathrm{~h}$ before lights off. There was no difference between groups (ANOVA). $n=3-6$. B.

Treatment with anti-PGE 2 antibody (2B5) does not affect food intake in normal mice. 2B5, or isotype control antibody (MOPC21) was injected intraperitoneally in the same volume and concentration as in the experiments shown in Fig. 4, and food intake monitored during two consecutive days. There was no difference between treatments or compared with mice injected with saline (ANOVA), $n=5$. 
Table 1. Change in mRNA expression of terminal prostanoid enzymes in tumor bearing mice

\begin{tabular}{llll}
\hline Enzyme & Assay ID & Fold change & Fold change \\
& & TB vs. Sham & TB+Indo vs. Sham \\
\hline mPGES-1 & Mm00452105_m1 & $1.22(0.89-1.67)$ & $1.10(0.87-1.38)$ \\
hPGDS & Mm00479846_m1 & $0.75(0.44-1.27)$ & $0.97(0.82-1.13)$ \\
IPGDS & Mm01330613_m1 & $1.46(1.11-1.92)^{*}$ & $1.24(1.11-1.38)^{*}$ \\
TXAS1 & Mm00495553_m1 & $0.77(0.57-1.03)$ & $1.06(0.84-1.33)$ \\
PGFS & Mm00481612_m1 & $0.97(0.82-1.15)$ & $1.35(0.89-1.21)$ \\
PGIS & Mm00447271_m1 & $0.97(0.79-1.20)$ & $1.04(0.85-1.26)$ \\
\hline
\end{tabular}

Figures within parentheses show $95 \%$ confidence interval. TB, tumor bearing mice;

TB+Indo, tumor bearing mice treated with indomethacin; Sham, sham implanted mice.

mPGES-1, microsomal prostaglandin E synthase-1; hPGDS, hematopoietic prostaglandin D synthase; IPGDS: lipocalin-type prostaglandin D synthase; TXAS: thromboxane A synthase 1; PGFS, prostamide/prostaglandin F synthase; PGIS, prostaglandin $\mathrm{I}_{2}$ (prostacyclin) synthase. * indicates $P<0.05 . n=6-7$. 
Axelsson, H., Lonnroth, C., Wang, W., Svanberg, E., Lundholm, K., 2005. Cyclooxygenase inhibition in early onset of tumor growth and related angiogenesis evaluated in EP1 and EP3 knockout tumor-bearing mice. Angiogenesis 8, 339-348.

Bosaeus, I., Daneryd, P., Svanberg, E., Lundholm, K., 2001. Dietary intake and resting energy expenditure in relation to weight loss in unselected cancer patients. Int. J. Cancer 93, 380-383. Brown, J.R., DuBois, R.N., 2005. COX-2: A Molecular Target for Colorectal Cancer Prevention. J. Clin. Oncol. 23, 2840-2855.

Cahlin, C., Gelin, J., Andersson, M., Lonnroth, C., Lundholm, K., 2005. The effects of nonselective, preferential-selective and selective COX-inhibitors on the growth of experimental and human tumors in mice related to prostanoid receptors. Int. J. Oncol. 27, 913-923.

Cahlin, C., Gelin, J., Delbro, D., Lonnroth, C., Doi, C., Lundholm, K., 2000a. Effect of cyclooxygenase and nitric oxide synthase inhibitors on tumor growth in mouse tumor models with and without cancer cachexia related to prostanoids. Cancer Res. 60, 1742-1749. Cahlin, C., Korner, A., Axelsson, H., Wang, W., Lundholm, K., Svanberg, E., 2000b. Experimental cancer cachexia: the role of host-derived cytokines interleukin (IL)-6, IL-12, interferon-gamma, and tumor necrosis factor alpha evaluated in gene knockout, tumor-bearing mice on C57 Bl background and eicosanoid-dependent cachexia. Cancer Res. 60, 5488-5493. Cao, C., Matsumura, K., Yamagata, K., Watanabe, Y., 1998. Cyclooxygenase-2 is induced in brain blood vessels during fever evoked by peripheral or central administration of tumor necrosis factor. Brain Res. Mol. Brain Res. 56, 45-56.

Daikoku, T., Tranguch, S., Chakrabarty, A., Wang, D., Khabele, D., Orsulic, S., Morrow, J.D., Dubois, R.N., Dey, S.K., 2007. Extracellular signal-regulated kinase is a target of cyclooxygenase-1-peroxisome proliferator-activated receptor-delta signaling in epithelial ovarian cancer. Cancer Res 67, 5285-5292.

Daikoku, T., Tranguch, S., Trofimova, I.N., Dinulescu, D.M., Jacks, T., Nikitin, A.Y., Connolly, D.C., Dey, S.K., 2006. Cyclooxygenase-1 is overexpressed in multiple genetically engineered mouse models of epithelial ovarian cancer. Cancer Res 66, 2527-2531.

Daikoku, T., Wang, D., Tranguch, S., Morrow, J.D., Orsulic, S., DuBois, R.N., Dey, S.K., 2005. Cyclooxygenase-1 is a potential target for prevention and treatment of ovarian epithelial cancer. Cancer Res. 65, 3735-3744.

Doggett, N.S., Jawaharlal, K., 1977. Some observations on the anorectic activity of prostaglandin F2alpha. Br J Pharmacol 60, 409-415.

Eckel, L.A., Langhans, W., Kahler, A., Campfield, L.A., Smith, F.J., Geary, N., 1998.

Chronic administration of OB protein decreases food intake by selectively reducing meal size in female rats. Am. J. Physiol. 275, R186-193.

Eguchi, N., Kaneko, T., Urade, Y., Hayashi, H., Hayaishi, O., 1992. Permeability of brain structures and other peripheral tissues to prostaglandins D2, E2 and F2 alpha in rats. J. Pharmacol. Exp. Ther. 262, 1110-1120.

Ek, M., Engblom, D., Saha, S., Blomqvist, A., Jakobsson, P.J., Ericsson-Dahlstrand, A., 2001. Inflammatory response: pathway across the blood-brain barrier. Nature 410, 430-431.

Ek, M., Kurosawa, M., Lundeberg, T., Ericsson, A., 1998. Activation of vagal afferents after intravenous injection of interleukin-1beta: role of endogenous prostaglandins. J. Neurosci. 18, 9471-9479.

Elander, L., Engstrom, L., Hallbeck, M., Blomqvist, A., 2007. IL-1beta and LPS induce anorexia by distinct mechanisms differentially dependent on microsomal prostaglandin $\mathrm{E}$ synthase-1. Am. J. Physiol. Regul. Integr. Comp. Physiol. 292, R258-267.

Elander, L., Ruud, J., Korotkova, M., Jakobsson, P.J., Blomqvist, A., 2010. Cyclooxygenase1 mediates the immediate corticosterone response to peripheral immune challenge induced by lipopolysaccharide. Neurosci. Lett. 470, 10-12. 
Elander, N., Ungerback, J., Olsson, H., Uematsu, S., Akira, S., Soderkvist, P., 2008. Genetic deletion of mPGES-1 accelerates intestinal tumorigenesis in APC(Min/+) mice. Biochem. Biophys. Res. Commun. 372, 249-253.

Engblom, D., Saha, S., Engstrom, L., Westman, M., Audoly, L.P., Jakobsson, P.J., Blomqvist, A., 2003. Microsomal prostaglandin E synthase-1 is the central switch during immuneinduced pyresis. Nat. Neurosci. 6, 1137-1138.

Engström, L., Ruud, J., Eskilsson, A., Larsson, A., Mackerlova, L., Kugelberg, U., Qian, H., Vasilache, A.M., Larsson, P., Engblom, D., Sigvardsson, M., Jönsson, J.-I., Blomqvist, A., 2012. Lipopolysaccharide-Induced Fever Depends on Prostaglandin E2 Production Specifically in Brain Endothelial Cells. Endocrinology 153, 4849-4861.

Fearon, K., Strasser, F., Anker, S.D., Bosaeus, I., Bruera, E., Fainsinger, R.L., Jatoi, A., Loprinzi, C., MacDonald, N., Mantovani, G., Davis, M., Muscaritoli, M., Ottery, F., Radbruch, L., Ravasco, P., Walsh, D., Wilcock, A., Kaasa, S., Baracos, V.E., 2011. Definition and classification of cancer cachexia: an international consensus. Lancet Oncol. 12, 489-495. Garcia-Bueno, B., Serrats, J., Sawchenko, P.E., 2009. Cerebrovascular cyclooxygenase-1 expression, regulation, and role in hypothalamic-pituitary-adrenal axis activation by inflammatory stimuli. J. Neurosci. 29, 12970-12981.

Gelin, J., Andersson, C., Lundholm, K., 1991. Effects of indomethacin, cytokines, and cyclosporin A on tumor growth and the subsequent development of cancer cachexia. Cancer Res 51, 880-885.

Gelin, J., Moldawer, L.L., Lonnroth, C., deMan, P., Svanborg-Eden, C., Lowry, S.F., Lundholm, K.G., 1988. Appearance of hybridoma growth factor/interleukin-6 in the serum of mice bearing a methylcholanthrene-induced sarcoma. Biochem. Biophys. Res. Commun. 157, 575-579.

Gupta, R.A., Tejada, L.V., Tong, B.J., Das, S.K., Morrow, J.D., Dey, S.K., DuBois, R.N., 2003. Cyclooxygenase-1 is overexpressed and promotes angiogenic growth factor production in ovarian cancer. Cancer Res. 63, 906-911.

Hanaka, H., Pawelzik, S.C., Johnsen, J.I., Rakonjac, M., Terawaki, K., Rasmuson, A., Sveinbjornsson, B., Schumacher, M.C., Hamberg, M., Samuelsson, B., Jakobsson, P.J., Kogner, P., Radmark, O., 2009. Microsomal prostaglandin E synthase 1 determines tumor growth in vivo of prostate and lung cancer cells. Proc. Natl. Acad. Sci. U S A 106, 1875718762.

Hellerstein, M.K., Meydani, S.N., Meydani, M., Wu, K., Dinarello, C.A., 1989. Interleukin-1induced anorexia in the rat. Influence of prostaglandins. J. Clin. Invest. 84, 228-235.

Horsley, V., Pavlath, G.K., 2003. Prostaglandin F2 $\alpha$ stimulates growth of skeletal muscle cells via an NFATC2-dependent pathway. J. Cell Biol. 161, 111-118.

Kamei, D., Murakami, M., Sasaki, Y., Nakatani, Y., Majima, M., Ishikawa, Y., Ishii, T., Uematsu, S., Akira, S., Hara, S., Kudo, I., 2010. Microsomal prostaglandin E synthase-1 in both cancer cells and hosts contributes to tumour growth, invasion and metastasis. Biochem. J. 425, 361-371.

Lal, J., 1984. Possible role of prostaglandins in the regulation of food intake in the newborn rat. Arch Int Pharmacodyn Ther 272, 140-149.

Langenbach, R., Morham, S.G., Tiano, H.F., Loftin, C.D., Ghanayem, B.I., Chulada, P.C., Mahler, J.F., Lee, C.A., Goulding, E.H., Kluckman, K.D., Kim, H.S., Smithies, O., 1995. Prostaglandin synthase 1 gene disruption in mice reduces arachidonic acid-induced inflammation and indomethacin-induced gastric ulceration. Cell 83, 483-492.

Langhans, W., Harlacher, R., Scharrer, E., 1989. Verapamil and indomethacin attenuate endotoxin-induced anorexia. Physiol. Behav. 46, 535-539.

Levine, A.S., Morley, J.E., 1981. The effect of prostaglandins (PGE2 and PGF2 alpha) on food intake in rats. Pharmacol. Biochem. Behav. 15, 735-738. 
Lonnroth, C., Moldawer, L.L., Gelin, J., Kindblom, L., Sherry, B., Lundholm, K., 1990. Tumor necrosis factor-alpha and interleukin-1 alpha production in cachectic, tumor-bearing mice. Int. J. Cancer 46, 889-896.

Lonnroth, C., Svaninger, G., Gelin, J., Cahlin, C., Iresjo, B., Cvetkovska, E., Edstrom, S., Andersson, M., Svanberg, E., Lundholm, K., 1995. Effects related to indomethacin prolonged survival and decreased tumor-growth in a mouse-tumor model with cytokine dependent cancer cachexia. Int. J. Oncol. 7, 1405-1413.

Lugarini, F., Hrupka, B.J., Schwartz, G.J., Plata-Salaman, C.R., Langhans, W., 2002. A role for cyclooxygenase-2 in lipopolysaccharide-induced anorexia in rats. Am. J. Physiol. Regul. Integr. Comp. Physiol. 283, R862-868.

Lundholm, K., Edstrom, S., Ekman, L., Karlberg, I., Bylund, A.C., Schersten, T., 1978. A comparative study of the influence of malignant tumor on host metabolism in mice and man: evaluation of an experimental model. Cancer 42, 453-461.

Lundholm, K., Gelin, J., Hyltander, A., Lonnroth, C., Sandstrom, R., Svaninger, G., Korner, U., Gulich, M., Karrefors, I., Norli, B., et al., 1994. Anti-inflammatory treatment may prolong survival in undernourished patients with metastatic solid tumors. Cancer Res. 54, 5602-5606. Mnich, S.J., Veenhuizen, A.W., Monahan, J.B., Sheehan, K.C., Lynch, K.R., Isakson, P.C., Portanova, J.P., 1995. Characterization of a monoclonal antibody that neutralizes the activity of prostaglandin E2. J. Immunol. 155, 4437-4444.

Morgan, E.T., Goralski, K.B., Piquette-Miller, M., Renton, K.W., Robertson, G.R., Chaluvadi, M.R., Charles, K.A., Clarke, S.J., Kacevska, M., Liddle, C., Richardson, T.A., Sharma, R., Sinal, C.J., 2008. Regulation of drug-metabolizing enzymes and transporters in infection, inflammation, and cancer. Drug. Metab. Dispos. 36, 205-216.

Murakami, M., Kudo, I., 2006. Prostaglandin E synthase: a novel drug targetfor inflammation and cancer. Curr. Pharm. Des. 12, 943-954.

Nakanishi, M., Montrose, D.C., Clark, P., Nambiar, P.R., Belinsky, G.S., Claffey, K.P., Xu, D., Rosenberg, D.W., 2008. Genetic deletion of mPGES-1 suppresses intestinal tumorigenesis. Cancer Res. 68, 3251-3259.

Ohinata, K., Suetsugu, K., Fujiwara, Y., Yoshikawa, M., 2006. Activation of prostaglandin E receptor EP4 subtype suppresses food intake in mice. Prostag. Oth. Lipid M. 81, 31-36.

Pecchi, E., Dallaporta, M., Thirion, S., Salvat, C., Berenbaum, F., Jean, A., Troadec, J.D., 2006. Involvement of central microsomal prostaglandin E synthase-1 in IL-1beta-induced anorexia. Physiol. Genomics 25, 485-492.

Plata-Salaman, C.R., 1994. Meal patterns in response to the intracerebroventricular administration of interleukin-1 beta in rats. Physiol. Behav. 55, 727-733.

Portanova, J.P., Zhang, Y., Anderson, G.D., Hauser, S.D., Masferrer, J.L., Seibert, K., Gregory, S.A., Isakson, P.C., 1996. Selective neutralization of prostaglandin E2 blocks inflammation, hyperalgesia, and interleukin 6 production in vivo. J. Exp. Med. 184, 883-891. Pourtau, L., Leemburg, S., Roux, P., Leste-Lasserre, T., Costaglioli, P., Garbay, B., Drutel, G., Konsman, J.P., 2011. Hormonal, hypothalamic and striatal responses to reduced body weight gain are attenuated in anorectic rats bearing small tumors. Brain Behav. Immun. 25, 777-786.

Ruud, J., Backhed, F., Engblom, D., Blomqvist, A., 2010. Deletion of the gene encoding MyD88 protects from anorexia in a mouse tumor model. Brain Behav. Immun. 24, 554-557. Ruud, J., Blomqvist, A., 2007. Identification of rat brainstem neuronal structures activated during cancer-induced anorexia. J. Comp. Neurol. 504, 275-286.

Samuelsson, B., Morgenstern, R., Jakobsson, P.J., 2007. Membrane prostaglandin E synthase1: a novel therapeutic target. Pharmacol. Rev. 59, 207-224.

Sandstrom, R., Gelin, J., Lundholm, K., 1990. The effect of indomethacin on food and water intake, motor activity and survival in tumour-bearing rats. Eur. J. Cancer 26, 811-814. 
Saper, C.B., Romanovsky, A.A., Scammell, T.E., 2012. Neural circuitry engaged by prostaglandins during the sickness syndrome. Nat. Neurosci. 15, 1088-1095.

Scaramuzzi, O.E., Baile, C.A., Mayer, J., 1971. Prostaglandins and food intake of rats. Experientia 27, 256-257.

Schneider, A., Guan, Y., Zhang, Y., Magnuson, M.A., Pettepher, C., Loftin, C.D., Langenbach, R., Breyer, R.M., Breyer, M.D., 2004. Generation of a conditional allele of the mouse prostaglandin EP4 receptor. Genesis 40, 7-14.

Smith, C.J., Zhang, Y., Koboldt, C.M., Muhammad, J., Zweifel, B.S., Shaffer, A., Talley, J.J., Masferrer, J.L., Seibert, K., Isakson, P.C., 1998. Pharmacological analysis of cyclooxygenase1 in inflammation. Proc. Natl. Acad. Sci. U S A 95, 13313-13318.

Steinbach, G., Lynch, P.M., Phillips, R.K.S., Wallace, M.H., Hawk, E., Gordon, G.B., Wakabayashi, N., Saunders, B., Shen, Y., Fujimura, T., Su, L.-K., Levin, B., Godio, L., Patterson, S., Rodriguez-Bigas, M.A., Jester, S.L., King, K.L., Schumacher, M., Abbruzzese, J., DuBois, R.N., Hittelman, W.N., Zimmerman, S., Sherman, J.W., Kelloff, G., 2000. The Effect of Celecoxib, a Cyclooxygenase-2 Inhibitor, in Familial Adenomatous Polyposis. New Engl. J. Med. 342, 1946-1952.

Tisdale, M.J., 2010. Cancer cachexia. Curr. Opin. Gastroenterol. 26, 146-151.

Tracey, K.J., Wei, H., Manogue, K.R., Fong, Y., Hesse, D.G., Nguyen, H.T., Kuo, G.C., Beutler, B., Cotran, R.S., Cerami, A., 1988. Cachectin/tumor necrosis factor induces cachexia, anemia, and inflammation. J. Exp. Med. 167, 1211-1227.

Trebino, C.E., Stock, J.L., Gibbons, C.P., Naiman, B.M., Wachtmann, T.S., Umland, J.P., Pandher, K., Lapointe, J.M., Saha, S., Roach, M.L., Carter, D., Thomas, N.A., Durtschi, B.A., McNeish, J.D., Hambor, J.E., Jakobsson, P.J., Carty, T.J., Perez, J.R., Audoly, L.P., 2003. Impaired inflammatory and pain responses in mice lacking an inducible prostaglandin $\mathrm{E}$ synthase. Proc. Natl. Acad. Sci. U S A 100, 9044-9049.

Tronche, F., Kellendonk, C., Kretz, O., Gass, P., Anlag, K., Orban, P.C., Bock, R., Klein, R., Schutz, G., 1999. Disruption of the glucocorticoid receptor gene in the nervous system results in reduced anxiety. Nat. Genet. 23, 99-103.

Wang, W., Andersson, M., Lonnroth, C., Svanberg, E., Lundholm, K., 2005. Prostaglandin E and prostacyclin receptor expression in tumor and host tissues from MCG 101-bearing mice: a model with prostanoid-related cachexia. Int. J. Cancer 115, 582-590.

Wang, W., Lonnroth, C., Svanberg, E., Lundholm, K., 2001. Cytokine and cyclooxygenase-2 protein in brain areas of tumor-bearing mice with prostanoid-related anorexia. Cancer Res. 61, 4707-4715.

West, D.B., Greenwood, M.R., Marshall, K.A., Woods, S.C., 1987. Lithium chloride, cholecystokinin and meal patterns: evidence that cholecystokinin suppresses meal size in rats without causing malaise. Appetite 8, 221-227.

Yang, L., Yamagata, N., Yadav, R., Brandon, S., Courtney, R.L., Morrow, J.D., Shyr, Y., Boothby, M., Joyce, S., Carbone, D.P., Breyer, R.M., 2003. Cancer-associated immunodeficiency and dendritic cell abnormalities mediated by the prostaglandin EP2 receptor. The Journal of Clinical Investigation 111, 727-735.

Zhang, Y., Shaffer, A., Portanova, J., Seibert, K., Isakson, P.C., 1997. Inhibition of cyclooxygenase-2 rapidly reverses inflammatory hyperalgesia and prostaglandin E2 production. J. Pharmacol. Exp. Ther. 283, 1069-1075. 